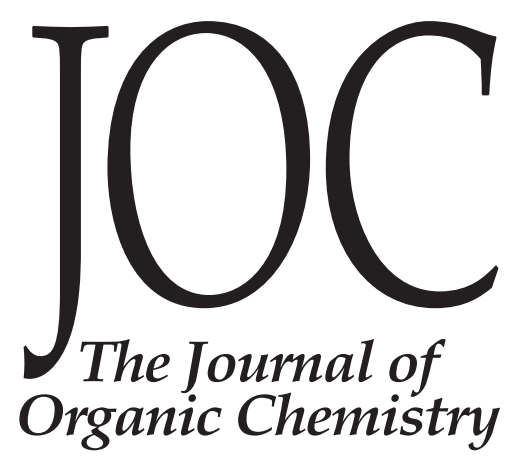

Volume 65, Number 13

J UNE 30, 2000

(c) Copyright 2000 by the American Chemical Society

\title{
Articles
}

\section{Synthesis and Properties of a Novel Family of Fluorous Triphenylphosphine Derivatives}

\author{
Bodo Richter, ${ }^{\dagger}$ Elwin de Wolf, ${ }^{\dagger}$ Gerard van Koten, ${ }^{\dagger}$ and Berth-J an Deelman*,, \\ Department of Metal-Mediated Synthesis, Debye Institute, Utrecht University, Padualaan 8, \\ $3584 \mathrm{CH}$ Utrecht, The Netherlands, and Elf Atochem VIissingen B.V., P.O. Box 70, \\ 4380 AB Vlissingen, The Netherlands
}

Received October 5, 1999

\begin{abstract}
A novel approach to the preparation of perfluorotail-functionalized triarylphosphines using a p-silyl substituent as the branching point has been developed. This approach enabled the attachment of between three and nine perfluorotails per phosphorus atom, resulting in the production of highly fluorous tris $\left[\mathrm{p}-\left(\mathrm{HH}, 1 \mathrm{H}, 2 \mathrm{H}, 2 \mathrm{H}\right.\right.$-perfluoroalkylsilyl)aryl ]phosphines, $\mathrm{P}\left[\mathrm{C}_{6} \mathrm{H}_{4}-\mathrm{p}-\mathrm{SiMe} \mathrm{e}_{3} \mathrm{n}\left(\mathrm{CH}_{2} \mathrm{CH}_{2} \mathrm{C}_{x} \mathrm{~F}_{2 x+1}\right)_{n}\right]_{3}$ ( $\mathrm{n}=1,2,3 ; \mathrm{x}=6,8$ ), containing between 50 and $67 \mathrm{wt} \%$ fluorine. ${ }^{31 \mathrm{P}} \mathrm{NMR}$ studies indicate that the phosphorus atoms, and consequently the $\sigma$-donor and $\pi$-acceptor properties of these phosphines, are not influenced by the electron-withdrawing perfluoroalkyltails. The fluorous triaryl phosphines are readily soluble in fluorous solvents and display fluorous phase preference in several fluorous bi phasic systems. The phase partitioning of these fluorous ligands, as well as their donor properties, is discussed in relation to their potential for fluorous biphasic catalyst separation.
\end{abstract}

\section{Introduction}

Since Horváth and Rábai 's ${ }^{1}$ initial report on using the fluorous biphase concept in catalysis, as an alternative to catalyst immobilization in water ${ }^{2}$ in ionic liquids, ${ }^{3}$ on surfaces of macromolecules, ${ }^{4}$ or on inorganic supports, ${ }^{5}$ this field has experienced a growing scientific and

* Author to whom correspondence should be addressed. Currently based at the Department of Metal-Mediated Synthesis of Utrecht University. Fax: +31 30 2523615. E-mail: b.j.deelman@chem.uu.nl.

+ Utrecht University.

₹ Elf Atochem Vlissingen B.V.

(1) (a) Horváth, I. T.; Rábai, J. Science 1994, 266, 72. (b) Horváth, I.; Rábai, J . U.S. Patent 5463082, 1995. (c) Horváth, I. T.; Kiss, G.; Cook, R. A.; Bond, J . E.; Stevens, P. A.; Rábai, J .; Mozeleski, E. J . J . Am. Chem. Soc. 1998, 120, 3133.

(2) (a) Kuntz, E. G. CHEMTECH 1987, 17, 570. (b) Herrmann, W. A.; Kohlpaintner, C. W. Angew. Chem., Int. Ed. Engl. 1993, 32, 1524. (c) Roundhill, D. M. Adv. Organomet. Chem. 1995, 38, 155. (d) Cornils, B. Angew. Chem., Int. Ed. Engl. 1995, 35, 1575. (e) Cornils, B., Herrmann, W. A., Eds. Aqueous-Phase Organometallic Catalysis. Concepts and Applications; VCH: Weinheim, Germany, 1996. industrial interest. ${ }^{6}$ Often, appropriate catalytic reactions for this new immobilization technique involve transition metal phosphine catalysts. Therefore, converting conventional phosphineligands into fluorous solvent soluble derivatives, whilekeeping their essential stereoelectronic properties intact, seems to be a key point. The metal complexes derived from these modified ligands are ex-

(3) (a) Chauvin, Y.; Olivier-Bourbigou, H. CHEMTECH 1995, 25, 26. (b) Chauvin, Y.; Mussmann, L.; Olivier, H. Angew. Chem., Int. Ed. Engl. 1995, 34, 2698. (c) Herrmann, W. A.; Böhm, V. P. W. J. Organomet. Chem. 1999, 572, 141.

(4) Knapen, J. W. J .; van der Made, A. W.; de Wilde, J. C.; van Leeuwen, P. W. N. M.; Wijkens, P.; Grove, D. M.; van Koten, G. Nature 1994, 372, 659.

(5) Petrucci, M. G. L.; Kakkar, A. K. Adv. Mater. 1996, 8, 251 and refereces therein.

(6) (a) Cornils, B. Angew. Chem., Int. Ed. Engl. 1997, 36, 2036. (b) Curran, D. P. Angew. Chem., Int. Ed. Engl. 1998, 37, 1174. (c) Horváth, I. T. Acc. Chem. Res. 1998, 31, 641. (d) de Wolf, E.; van Koten, G. Deelman, B.-J. Chem. Soc. Rev. 1999, 28, 37. 
Table 1. Fluorous Phosphines Based on Different Hydrocarbon Spacers

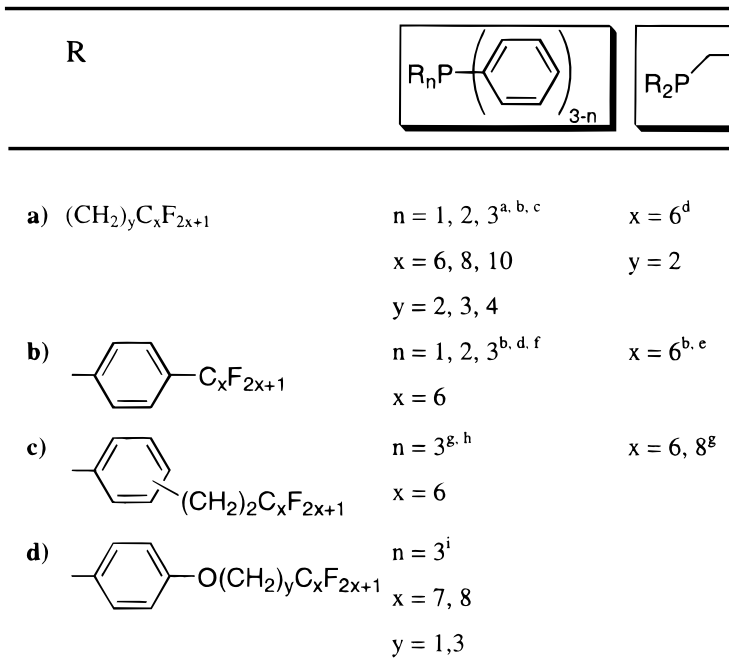

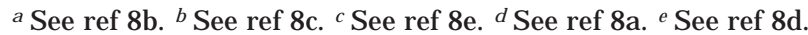
f See ref 9. ${ }^{g}$ See ref $7 a .{ }^{h}$ See ref $8 f .{ }^{i}$ See ref 12.

pected to be preferentially soluble in apolar perfluorinated solvents, as well as in supercritical carbon dioxide. ${ }^{7}$

Only a limited number of fluorous versions of catalytically important phosphines, such as $\mathrm{PPh}_{3}$ and $\mathrm{R}_{2} \mathrm{PCH}_{2}-$ $\mathrm{CH}_{2} \mathrm{PR}_{2}\left(\mathrm{R}=\right.$ alkyl, aryl), have been reported. ${ }^{8}$ The most common synthetic approach is the attachment of aliphatic fluorocarbon chains either directly to the phosphorus atom or to the organic substituents of a particular phosphine. However, in all known cases, a nonfluorous spacer group has been necessary to insulate the phosphorus atom from the strongly electron-withdrawing perfluoroalkyltail (Table 1).

In previous studies, either (a) one or more $\mathrm{CH}_{2}$ groups, (b) an aryl ring, or (c) both have been used as spacer, ${ }^{7 a, b, 8,9}$ leading to fluorous alkyl and aryl phosphines that have also been referred to as "pony" or "pigtail" phosphines. In addition, reports of a number of aryl phosphines with perfluoroalkyl and perfluoroalkyl ether chains containing aromatic $\mathrm{C}-\mathrm{F}$ bonds have been published. ${ }^{10}$ Because these bonds are known to be easily activated by late transition metal complexes, ${ }^{11}$ these ligands appear to be less suitable for catalysis. More recently, fluorinated alkoxy groups (d) have been used to increase the solubil-

(7) (a) Kainz, S.; Koch, D.; Baumann, W.; Leitner, W. Angew. Chem. Int. Ed. Engl. 1997, 36, 1628. (b) Caroll, M. A.; Holmes, A. B. Chem. Commun. 1998, 1395. (c) Morita, D. K.; Pesiri, D. R.; David, S. A.; Glaze, W. H.: Tumas, W. Chem. Commun. 1998, 1397. (d) Hadida, S. Super, M. S.; Beckman, E. J .; Curran, D. P. J . Am. Chem. Soc. 1997, 119, 7406.

(8) (a) Betzemeier, B.; Knochel, P. Angew. Chem., Int. Ed. Engl. 1997, 36, 2623. (b) Langer, F.; Püntener, K.; Stürmer, K.; Knochel, P. Tetrahedron: Asymmetry 1997, 8, 715. (c) Bhattacharya, P.; Gudmunsen, D.; Hope, E. G.; Kemmitt, R. D. W.; Paige, D. R.; Stuart, A. M.J Chem. Soc., Perkin Trans. 1 1997, 3609. (d) Hope, G. H.; Kemmitt, R. D. W.; Stuart, A. M. J . Chem. Soc., Dalton Trans. 1998, 3765. (e) Alvey, L. J .; Rutherford, D.; J uliette, J. J . J .; Gladysz, J . A. J . Org. Chem. 1998, 63, 6302. (f) Kling, R.; Sinou, D.; Pozzi, G.; Chopin, A.; Quignard F.; Busch, S.; Kainz, S.; Koch, D.; Leitner, W. Tetrahedron Lett. 1998, 39, 9439.

(9) (a) Kainz, S.; Luo, Z.; Curran, D. P.; Leitner, W. Synthesis 1998, 1425. (b) Fawcett, J .; Hope, E. G.; Kemmitt, R. D. W.; Paige, D. R. Russell, D. R.; Stuart, A. M. J . Chem. Soc., Dalton Trans. 1998, 3751.

(10) (a) Gopal, H.; Tamborski, C. J . Fluorine Chem. 1979, $13,337$. (b) Gopal, H.; Snyder, C. E.; Tamborski, C. J . Fluorine Chem. 1979, $14,511$.

(11) (a) Kiplinger, L. J .; Richmond, T. G.; Osterberg, C. E. Chem. Rev. 1994, 94, 373. (b) Atherton, M. J .; Coleman, K. S.; Fawcett, J.; Holloway, J . H.; Hope, E. G.; Karaçar, A.; Russell, D. R.; Saunders, G. C. J . Chem. Soc., Dalton Trans. 1996, 3215.

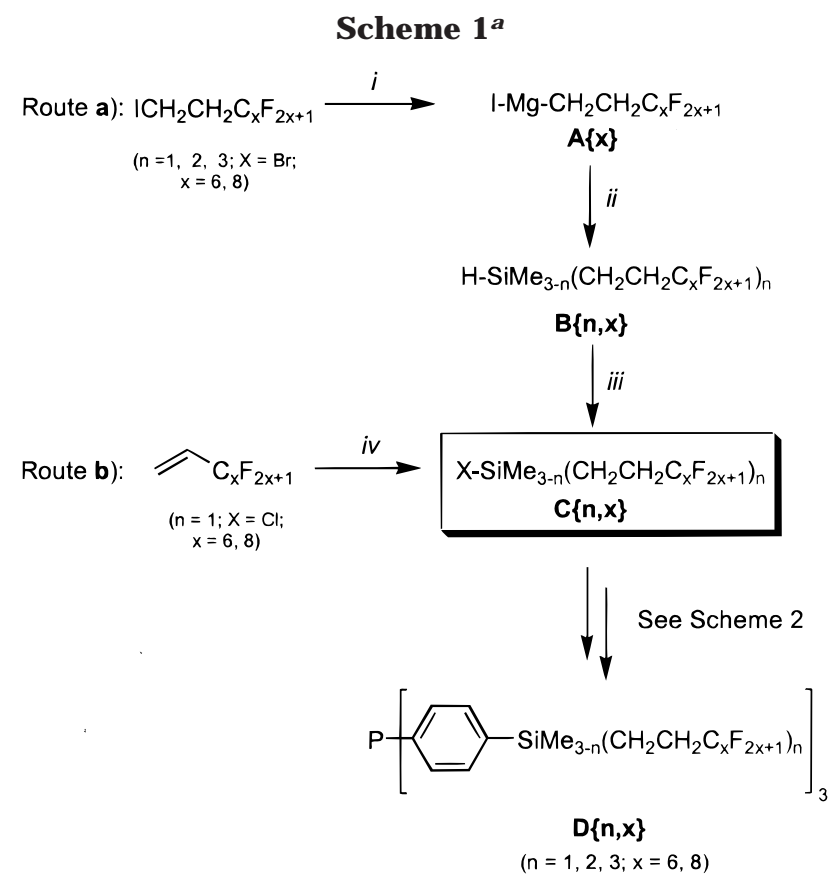

a Reagents and conditions: (i) 30-fold excess of $\mathrm{Mg}$, diethyl ether, $25^{\circ} \mathrm{C}$; (ii) $\mathrm{HSi}(\mathrm{Me})_{3-n} \mathrm{Cl}_{n}, \mathrm{Et}_{2} \mathrm{O}$; (iii) $\mathrm{Br}_{2}, \mathrm{n}$-hexane $(\mathrm{n}=1$, 2), n-hexane/FC-72 ( $=3$ ), $25^{\circ} \mathrm{C}$; (iv) $1.5 \mathrm{HSiMe}_{2} \mathrm{Cl}, \mathrm{H}_{2} \mathrm{PtCl}_{6}$ (aq), reflux.

ity of triarylphosphines in fluorous solvents. ${ }^{12}$ The observed catalytic activities of fluorous phase soluble catalysts derived from the phosphines in Scheme 1 are generally an order of magnitude lower than those of their nonfluorous analogues. ${ }^{13}$

Inspired by our work on dendrimeric structures containing silicon branching points ${ }^{4}$ and work by Curran et al. ${ }^{14}$ on the use of fluorous silyl tags and fluorous tin hydrides in organic synthesis, we became interested in developing aryl phosphine ligands with p-SiMe $\mathrm{CH}_{2} \mathrm{CH}_{2}$ spacer groups (Figure 1). We anticipated that the silicon would provide a positive inductive effect to the aromatic system, in that way neutralizing the electron-withdrawing effect of the perfluoro chain. Furthermore the successive substitution of methyl for $\left(\mathrm{CH}_{2}\right)_{2} \mathrm{C}_{x} \mathrm{~F}_{2 x+1}(\mathrm{x}=6$, 8) groups allows the attachment of up to nine perfluoroalkyl chains per $\mathrm{P}$ atom for a homoleptic triaryl phosphine (Figure 1), which is expected to lead to a reduction in

(12) Sinou, D.; Pozzi, G.; Hope, E. G.; Stuart, A. Tetrahedron Lett. 1999, 40, 849.

(13) (a) For example, in the case of olefin hydroformylation, the activity of the $\mathrm{Rh} / \mathrm{P}\left[\mathrm{CH}_{2} \mathrm{CH}_{2}\left(\mathrm{CF}_{2}\right)_{5} \mathrm{CF}_{3}\right]_{3}$ system is ca. 10 times less than that of $\mathrm{Rh} / \mathrm{PPh}_{3}{ }^{1 \mathrm{C}}$ In hydrogenation reactions employing similar catalysts, $16-1073$ turnovers in $24 \mathrm{~h}^{13 \mathrm{~b}}$ and $88-108$ turnovers in 8 $\mathrm{h}^{13 \mathrm{c}}$ have been observed, which are modest compared to, e.g., Wilkinson's catalyst $\mathrm{RhCl}\left(\mathrm{PPh}_{3}\right)_{3}\left(150-600\right.$ turnovers/h). ${ }^{13 d}$ The positive effect of using triaryl phosphines instead of trialkyl phosphines is well-known in catalytic hydrogenation ${ }^{13 e, f}$ and has been attributed to the lower basicity of triarylphosphines. Hence, for optimum activity, fluorous triaryl phosphines with steric and electronic properties that are closely comparable to those of $\mathrm{PPh}_{3}$ would be highly desirable. (b) Haar, C. M.; Huang, J .; Nolan, S. P.; Petersen, J . L. Organometallics 1998, 17, 5018. (c) Rutherford, D.; J uliette, J . J . J .; Rocaboy, C.; Horváth, I. T.; Gladysz, J . A. Catal. Today 1998, 42, 381. (d) Derived from data in: Osborn, J. A.; J ardine, F. H.; Young, J . F.; Wilkinson, G. J . Chem. Soc. A 1966, 1711. (e) Chaloner, P. A.; Esteruelas, M. A.; J oó, F.; Oro, L. A. Homogeneous Hydrogenation; Kluwer Academic Publishers: Boston, MA, 1994; pp 8-9. (f) Montelatici, S.; van der Ent, A.; Osborn, J . A.; Wilkinson, G. J . Chem. Soc. A 1968, 1054.

(14) (a) Curran, D. P.; Ferritto, R.; Ye, H. Tetrahedron Lett. 1998 39, 4937. (b) Curran, D. P.; Hadida, S.; Kim, S.-Y.; Luo, Z. J . Am. Chem. Soc. 1999, 121, 6607 and references therein. 


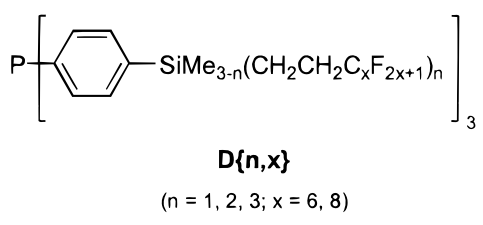

Figure 1. Fluorous triphenyl phosphines with various degrees of fluorous character through the use of silicon as a branching point.

ligand and/or catalyst leaching during fluorous biphasic separation.

In our previous work on fluorous triphenylphosphines $\mathbf{D}\{\mathbf{1}, \mathbf{x}\}(\mathbf{x}=6,8)$ and in their successful application to the recycling of highly active rhodium-based hydrogenation catalysts by fluorous biphase separation, ${ }^{15}$ we obtained indications that fluorous phosphines with higher fluorine content could be advantageous, because recycling of the intact catalyst was limited by the loss of free phosphine ( 8 and $2 \%$ per cycle, respectively). Here, we present (i) a full report on the preparation of fluorous triaryl phosphines $\mathbf{D}\{\mathbf{1}, \mathbf{x}\}$; (ii) a new, versatile synthetic route for the synthesis of higher substituted fluorous triaryl phosphines $\mathbf{D}\{\mathbf{n}, \mathbf{x}\}(n=2,3)$ involving the use of a p-Si $(\mathrm{Me})_{3-n}\left[\left(\mathrm{CH}_{2}\right)_{2}\right]_{n}$ spacer $(n=1,2,3)$; and (iii) a study on the solubility of the new phosphines in organic and fluorous solvents and their partition coefficients in fluorous biphasic solvent systems.

\section{Results and Discussion}

Synthesis. Scheme 1 gives an overview of the two routes used to obtain fluorous silanes $\mathbf{C}\{\mathbf{n}, \mathbf{x}\}$, which serve as precursors for the preparation of phosphines $\mathbf{D}\{\mathbf{n}, \mathbf{x}\}$. Here $n$ signifies the number of fluorotails per silicon atom, whereas $x$ represents the number of carbons in the $\mathrm{C}_{x} \mathrm{~F}_{2 x+1}$ fluorotail. The synthesis of the fluorous phosphines $\mathbf{D}\{\mathbf{n}, \mathbf{x}\}$ starts from either $(1 \mathrm{H}, 1 \mathrm{H}, 2 \mathrm{H}, 2 \mathrm{H}$-perfluoro-1-alkyl)dimethylchl orosilanes $\mathbf{C}\{\mathbf{1}, \mathbf{x}\}^{15}$ or bis- and tris $(1 \mathrm{H}, 1 \mathrm{H}, 2 \mathrm{H}, 2 \mathrm{H}$-perfluoro-1-alkyl)bromosilanes $\mathbf{C}\{\mathbf{n}, \mathbf{x}\}$ $(n=2,3 ; x=6$, 8; Scheme 1). The silanes $\mathbf{C}\{\mathbf{1}, \mathbf{x}\}$ are commercially available but can also be obtained through hydrosilylation of $1 \mathrm{H}, 1 \mathrm{H}, 2 \mathrm{H}$-perfluoro-1-octene or -decene (step iv, Scheme 1; ${ }^{16}$ Table 2, entries 1 and 5). The internal ol efins trans-Me $(\mathrm{H}) \mathrm{C}=\mathrm{CF}\left(\mathrm{C}_{\mathrm{y}} \mathrm{F}_{2 \mathrm{z}+1}\right)(\mathrm{y}=5,7)$ were obtained as side products (21-40\%) and are responsible for the rather moderate yield of the hydrosilylation step. Most likely they are formed by the decomposition of the unstable Markovnikov addition product. ${ }^{17}$

The route via the Grignard reagents of the $1 \mathrm{H}, 1 \mathrm{H}$,$2 \mathrm{H}, 2 \mathrm{H}$-perfluoro-1-alkyl iodides $(\mathbf{A}\{\mathbf{x}\})$ and reaction with chlorosilanes $\mathrm{HSi}(\mathrm{Me})_{3-x} \mathrm{Cl}_{\times}$(Scheme 1, route a), which

(15) (a) Richter, B.; Deelman, B.-J .; van Koten, G. Eur. Pat. Appl. 98203308.6, Sept 30, 1998. (b) Richter, B.; Deelman, B.-J .; van Koten, G. J . Mol. Catal. A: Chem. 1999, 145, 317. (c) Deelman, B.-J .; Richter, B.; Van Koten, G. Book of Abstracts, Cerc3 Young Chemists Workshop: Homogeneous Catalysis, University of Rostock, Rostock, Germany, Apr 21-24, 1999. (d) Deelman, B.-J .; Richter, B.; Van Koten G. Book of Abstracts, 218th American Chemical Society National Meeting, New Orleans, LA, Aug 22-26, 1999. (e) Richter, B.; Spek, A. L.; van Koten, G.; Deelman, B.-J J . Am. Chem. Soc. 2000, 122, 3945.

(16) Améduri, B.; Boutevin, B.; Nouiri, M.; Talbi, M. J . Fluorine Chem. 1995, 74, 191.

(17) Kim, Y. K.; Pierce, O. R.; Bajzer, W. X.; Smith, A. G. J . Fluorine Chem. 1971/72, 1, 203.
Table 2. Yields Obtained in the Synthesis of Fluorous Silanes According to the Methods Used in Scheme 1

\begin{tabular}{cllllc}
\hline entry & $\{\mathrm{n}, \mathbf{x}\}$ & method & $\mathbf{B}\{\mathbf{n}, \mathbf{x}\}^{\mathrm{a}}$ & $\mathbf{C}\{\mathbf{n}, \mathbf{x}\}^{\mathrm{b}}$ & $\begin{array}{c}\text { total yield } \\
(\%)^{\mathrm{c}}\end{array}$ \\
\hline 1 & $\{1,6\}$ & $\mathrm{b}$ & - & $60(63)^{\mathrm{d}}$ & 60 \\
2 & $\{1,6\}$ & $\mathrm{a}$ & 68 & nd & nd \\
3 & $\{2,6\}$ & $\mathrm{a}$ & 79 & 99 & 78 \\
4 & $\{3,6\}$ & $\mathrm{a}$ & $78(70)^{\mathrm{e}}$ & $80(99)^{\mathrm{f}}$ & 62 \\
5 & $\{1,8\}$ & $\mathrm{b}$ & - & $79(66)^{\mathrm{d}}$ & 79 \\
6 & $\{2,8\}$ & $\mathrm{a}$ & 70 & 80 & 56 \\
7 & $\{3,8\}$ & $\mathrm{a}$ & 75 & 92 & 69
\end{tabular}

a Based on $\mathrm{C}_{x} \mathrm{~F}_{2 x+1} \mathrm{C}_{2} \mathrm{H}_{4}$ l, yield of Grignard reaction included. b Based on $\mathrm{C}_{x} \mathrm{~F}_{2 x+1} \mathrm{CH}=\mathrm{CH}_{2}(n=1)$ or $\mathbf{B}\{\mathbf{n}, \mathbf{x}\}(n=2,3)$. ${ }^{\mathrm{c}}$ Based on $\mathrm{C}_{x} \mathrm{~F}_{2 x+1} \mathrm{CH}=\mathrm{CH}_{2}(n=1)$ or $\mathrm{C}_{x} \mathrm{~F}_{2 x+1} \mathrm{C}_{2} \mathrm{H}_{4} \mathrm{l}(\mathrm{n}=2,3)$. d See ref 16. ${ }^{\text {e See ref } 18 a .}{ }^{\text {f }}$ See ref $18 b$.

was reported previously for $\mathbf{B}\{\mathbf{3}, \mathbf{x}\}(\mathbf{x}=6,10),{ }^{18}$ has been used to synthesize a six-member library of fluorous alkylsilanes $\mathbf{B}\{\mathbf{n}, \mathbf{x}\}$ ( $n=1,2,3 ; \mathbf{x}=6,8)$, with compounds $\mathbf{B}\{\mathbf{2}, \mathbf{X}\}$ and $\mathbf{B}\{\mathbf{3}, \mathbf{8}\}$ as the new derivatives. This route also allows more efficient access to silanes $\mathbf{B}\{\mathbf{1}, \mathbf{x}\}$ than provided by hydrosilylation followed by reduction with $\mathrm{LiAlH}_{4}$ (68\% compared to 55\% yield, $\mathrm{x}=6$; Table 2, entry 2). ${ }^{16,19}$

The reactions with dichloromethylsilane and trichlorosilane were straightforward and yielded the fluoroalkylsilanes $\mathbf{B}\{\mathbf{n}, \mathbf{x}\}$ as air-stable and easy-to-handle materials. Bromination of $\mathbf{B}\{\mathbf{n}, \mathbf{x}\}$, following modified literature procedures for $\mathbf{C}\{\mathbf{3}, \mathbf{x}\}(\mathbf{x}=6,10),{ }^{18 b, c}$ afforded bromosilanes $\mathbf{C}\{\mathbf{n}, \mathbf{x}\}$. An overview of the yields of each step in Scheme 1 is given in Table 2.

Two general strategies for the synthesis of the fluorous aryl phosphines have been followed, specifically, route $a$, the reaction of lithiated $p$-(fluoroal kylsilyl)bromobenzene $\mathbf{E}\{\mathbf{n}, \mathbf{x}\}$ with $\mathrm{PCl}_{3}$ or $\mathrm{P}(\mathrm{OMe})_{3}$, and route $\mathrm{b}$, the reaction of fluoroalkylhal osilanes $\mathbf{C}\{\mathbf{n}, \mathbf{x}\}(n=1,2,3)$ with lithiated tris(p-bromophenyl)phosphine (Scheme 2). To be able to compare the effect of the fluoroalkylsilyl substituents with that of a regular methyl group, the known trimethylsilyl derivative $\mathbf{D}\{\mathbf{0}\}^{20}$ was prepared as well, following the same synthetic procedure.

Route a (Scheme 2). Silyl chlorides $\mathbf{C}\{\mathbf{1}, \mathbf{x}\}$ were reacted with $p$-bromophenyllithium, which was obtained by lithiation of 1,4-bromoiodobenzene or (less expensive) 1,4-dibromobenzene using an improved literature procedure. ${ }^{21}$ The yields of aryl derivatives $\mathbf{E}\{\mathbf{n}, \mathbf{x}\}$ are listed in Table 3. Col orless liquid $\mathbf{E}\{\mathbf{1}, \mathbf{6}\}$ and white, waxy solid $\mathbf{E}\{\mathbf{1}, \mathbf{8}\}$ are soluble in benzene, chloroform, and hexane. Minor amounts of $1,4-\left[\mathrm{SiMe}_{2}\left(\mathrm{CH}_{2}\right)_{2} \mathrm{C}_{x} \mathrm{~F}_{2 x+1}\right]_{2} \mathrm{C}_{6} \mathrm{H}_{4}(\mathrm{x}=6$, 8) were formed as side products. A similar side product has been reported in the copper(I)-mediated coupling reaction of $\mathrm{CF}_{3}\left(\mathrm{CF}_{2}\right)_{5}$ l with $\mathrm{p}$-bromoiodobenzene. ${ }^{8 \mathrm{~d}}$ The route to $\mathbf{E}\{\mathbf{1}, \mathbf{x}\}$ has also been used in our laboratory for the synthesis of fluorous $\left[\mathrm{NiCl}\left\{2,6-\left(\mathrm{CH}_{2} \mathrm{NMe}_{2}\right)_{2} \mathrm{C}_{6} \mathrm{H}_{2}-4-\right.\right.$

(18) (a) Boutevin, B.; Guida-Pietrasanta, F.; Ratsimihety, A.; Caporiccio, G.; Gornowitz, G. J . FluorineChem. 1993, 60, 211. (b) Studer, A.; Curran, D. P. Tetrahedron 1997, 53, 6681. (c) Studer, A.; J eger, P.; Wipf, P.; Curran, D. P. J . Org. Chem. 1997, 62, 2917.

(19) The polyfluoroalkyl iodides exhibit a high tendency to form Wurtz-coupling products in the Grignard reaction, especially at temperatures above $25{ }^{\circ} \mathrm{C}$ and at concentrations $\geq 0.4 \mathrm{M}$. However, the amount of radical dimer could be kept below $10 \%$ by performing the Grignard reaction slowly ( $15 \mathrm{~h}$ ) at room temperature and at $\leq 0.22 \mathrm{M}$ concentrations in $\mathrm{Et}_{2} \mathrm{O}$.

(20) First reported by: Frisch, K. C.; Lyons, H. J . Am. Chem. Soc 1953, 75, 4078

(21) (a) Gilman, H.; J ones, R. G. J . Am. Chem. Soc. 1941, 63, 1443. (b) J ones, R. G.; Gilman, H. In Organic Reactions; Adams, R., Ed.; Wiley: New York, 1951; Vol. 6, p 339. (c) Neumann, H.; Seebach, D. Tetrahedron Lett. 1976, 4839. 


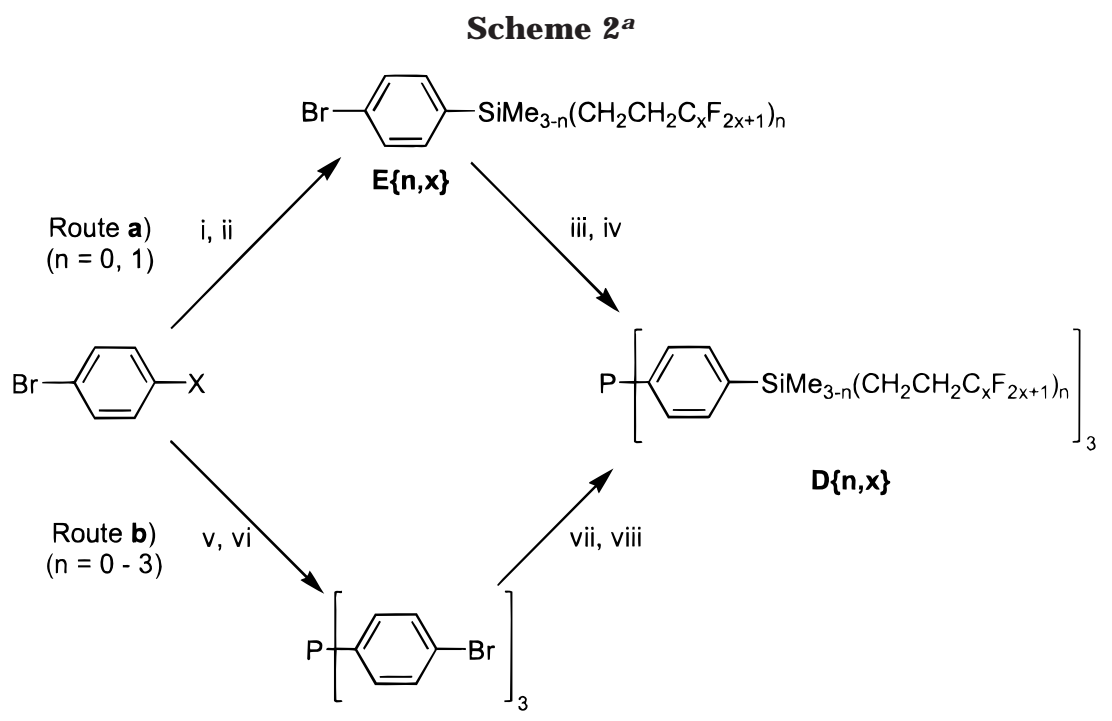

a Reagents and conditions: (i) $\mathrm{X}=\mathrm{I}$, nBuLi, n-hexane/n-pentane, $0^{\circ} \mathrm{C}$; (ii) $\mathbf{C}\{\mathbf{n}, \mathbf{x}\}, \mathrm{THF} / \mathrm{n}$-pentane, $-78^{\circ} \mathrm{C}$ then room temperature; (iii) 2 tBuLi, n-hexane, $-78{ }^{\circ} \mathrm{C}$ then room temperature, or ${ }^{\mathrm{B}} \mathrm{BuLi}$, n-hexane, $0{ }^{\circ} \mathrm{C}$ then room temperature; (iv) $1 / 3 \mathrm{PCl}{ }_{3}$ or $1 / 3 \mathrm{P}(\mathrm{OMe})_{3}, \mathrm{n}$-hexane/ $\mathrm{THF},-78{ }^{\circ} \mathrm{C}$ then room temperature; (v) $\mathrm{X}=\mathrm{Br},{ }^{\mathrm{nBuLi}}$, n-hexane/Et $\mathrm{H}_{2} \mathrm{O}$, room temperature; (vi) ${ }^{1 / 3} 3 \mathrm{PCl}_{3}, \mathrm{n}-\mathrm{hexane} / \mathrm{Et}_{2} \mathrm{O},-78{ }^{\circ} \mathrm{C}$ then room temperature; (vii) $6{ }^{\mathrm{t} B u L i}, \mathrm{Et}_{2} \mathrm{O} /$ hexane, $-78{ }^{\circ} \mathrm{C}$; (viii) $3 \mathbf{C}\{\mathbf{n}, \mathbf{x}\}, \mathrm{Et}_{2} \mathrm{O} / \mathrm{n}$-hexane, $-78{ }^{\circ} \mathrm{C}$ then room temperature.

Table 3. Yields Obtained in the Synthesis of Nonfluorous and Fluorous Compounds E and D According to Methods $a$ and $b$ in Scheme 2

\begin{tabular}{cclcc}
\hline entry & method & $\{n, x\}$ & $\begin{array}{c}\mathbf{E}\{\mathbf{n}, \mathbf{x}\}^{\mathrm{a}} \\
(\%)\end{array}$ & $\begin{array}{c}\mathbf{D}\{\mathbf{n}, \mathbf{x}\}^{\mathrm{b}} \\
(\%)\end{array}$ \\
\hline la & $\mathrm{a}^{\mathrm{c}, \mathrm{e}}$ & $\{0\}$ & 98 & 75 \\
1b & $\mathrm{a}^{\mathrm{d}, \mathrm{f}}$ & $\{0\}$ & 98 & 40 \\
2 & $\mathrm{~b}$ & $\{0\}$ & - & 98 \\
3 & $\mathrm{ac}^{\mathrm{c}, \mathrm{f}}$ & $\{1,6\}$ & 83 & 62 \\
4 & $\mathrm{~b}$ & $\{1,6)$ & - & 77 \\
5 & $\mathrm{~b}$ & $\{2,6\}$ & - & 98 \\
6 & $\mathrm{~b}$ & $\{3,6\}$ & - & 86 \\
$7 \mathrm{a}$ & $\mathrm{a}, \mathrm{e}$ & $\{1,8\}$ & 87 & 48 \\
$7 \mathrm{~b}$ & $\mathrm{a}, \mathrm{f}$ & $\{1,8\}$ & 87 & 41 \\
8 & $\mathrm{~b}$ & $\{2,8\}$ & - & 90 \\
9 & $\mathrm{~b}$ & $\{3,8\}$ & - & 88
\end{tabular}

a Based on $\mathbf{C}\{\mathbf{n}, \mathbf{x}\}$. b ${ }^{\text {Y }}$ ield based on $\mathbf{E}\{\mathbf{0}\}, \mathbf{E}\{\mathbf{1}, \mathbf{x}\}$ (route a), $\mathbf{C}\{\mathbf{0}\}$, or $\mathbf{C}\{\mathbf{n}, \mathbf{x}\}$ (route b). ${ }^{\mathrm{C}}$ Using ${ }^{\mathrm{t} B u L i}$ in step ii. d Using ${ }^{\mathrm{n}} \mathrm{BuL} i$ in step ii. ${ }^{e}$ Using $\mathrm{P}(\mathrm{OMe})_{3}$ in step iii. ${ }^{\mathrm{f}}$ Using $\mathrm{PCl}_{3}$ in step iii.

$\left.\left.\mathrm{SiMe}\left(\mathrm{CH}_{2}\right)_{2}\left(\mathrm{CF}_{2}\right)_{5} \mathrm{CF}_{3}\right\}\right]$, a model catalyst for the sel ective 1:1 Kharasch addition of $\mathrm{CCl}_{4}$ to methyl methacrylate under fluorous conditions. ${ }^{22}$

Compounds $\mathbf{E}\{\mathbf{1}, \mathbf{x}\}$ were easily lithiated using either tBuLi (1:2 molar ratio) or ${ }^{\mathrm{B}} \mathrm{BuLi}$ (1:1 molar ratio). The fact that the yields were lower than expected is the result of incomplete lithiation rather than side reactions $\left({ }^{1} \mathrm{H}\right.$ NMR). Lithiation using ${ }^{n} B u L i$ instead of tBuLi afforded similar yields, but proved to be more time-consuming. Metathesis of lithiated $\mathbf{E}\{\mathbf{1}, \mathbf{x}\}$ with $\mathrm{PCl}_{3}$ or $\mathrm{P}(\mathrm{OMe})_{3}$ at $0{ }^{\circ} \mathrm{C}$ afforded the desired phosphine ligands $\mathbf{D}\{\mathbf{1}, \mathbf{x}\}$ in moderate overall yields (Table 4).

Route b (Scheme 2). After several unsuccessful attempts to lithiate aryl bromides $\mathbf{E}\{\mathbf{n}, \mathbf{x}\}$ bearing more than one fluorotail $(n>1)$, we decided to introduce the fluoroalkylsilyl group by reaction with lithiated tris(pbromophenyl)phosphine. The latter was synthesized in $71 \%$ yield by optimization of a literature procedure. ${ }^{23}$ The

(22) Kleijn, H.; J astrzebski, J . T. B. H.; Gossage, R. A.; Kooijman, H.; Spek, A. L.; van Koten, G. Tetrahedron 1997, 54, 1145.

(23) (a) See Experimental Section. (b) Benassi, R.; Schenetti, M. L.; Taddei, F.; Vivarelli, P.; Dembech, P. J. Chem. Soc., Perkin Trans. 2 1974, 1338. (c) Ravindar, V.; Hemling, H.; Schumann, H.; Blum, J. Synth. Commun. 1992, 22, 841.
Table 4. Overall Yields of Aryl Phosphines D Based on the Different Starting Materials Used

\begin{tabular}{ccccccc}
\hline entry & method & $\{\mathrm{n}, \mathrm{x}\}$ & $\begin{array}{c}\mathbf{C}\{\mathbf{n}, \mathbf{x}\} \\
(\%)\end{array}$ & $\begin{array}{c}\mathrm{PCl}_{3} \\
(\%)\end{array}$ & $\begin{array}{c}\mathrm{P}(\mathrm{OMe})_{3} \\
(\%)\end{array}$ & $\begin{array}{c}\mathrm{p}-\mathrm{BrC}_{6} \mathrm{H}_{4} \mathrm{X} \\
(\%)\end{array}$ \\
\hline $1 \mathrm{a}$ & $\mathrm{a}^{\mathrm{a}}$ & $\{0\}$ & 75 & - & 90 & $68(\mathrm{X}=1)$ \\
$1 \mathrm{~b}$ & $\mathrm{a}^{\mathrm{b}}$ & $\{0\}$ & 40 & 58 & - & $36(\mathrm{X}=1)$ \\
2 & $\mathrm{~b}$ & $\{0\}$ & 98 & 70 & - & $70(\mathrm{X}=\mathrm{Br})$ \\
3 & $\mathrm{a}^{\mathrm{a}}$ & $\{1,6\}$ & 51 & 68 & - & $46(\mathrm{X}=1)$ \\
4 & $\mathrm{~b}$ & $\{1,6\}$ & 77 & 55 & - & $55(\mathrm{X}=\mathrm{Br})$ \\
5 & $\mathrm{~b}$ & $\{2,6\}$ & 98 & 64 & - & $64(\mathrm{X}=\mathrm{Br})$ \\
6 & $\mathrm{~b}$ & $\{3,6\}$ & 88 & 61 & - & $61(\mathrm{X}=\mathrm{Br})$ \\
$7 \mathrm{a}$ & $\mathrm{a}^{\mathrm{a}}$ & $\{1,8\}$ & 42 & - & 65 & $38(\mathrm{X}=1)$ \\
$7 \mathrm{~b}$ & $\mathrm{a}^{\mathrm{b}}$ & $\{1,8\}$ & 35 & 57 & - & $35(\mathrm{X}=1)$ \\
8 & $\mathrm{~b}$ & $\{2,8\}$ & $90^{c}$ & 71 & - & $71(\mathrm{X}=\mathrm{Br})$ \\
9 & $\mathrm{~b}$ & $\{3,8\}$ & $88^{c}$ & 69 & - & $70(\mathrm{X}=\mathrm{Br})$
\end{tabular}

a Using tBuLi in step ii. b Using ${ }^{n} B u L i$ in step ii. c Using a $10 \%$ excess of $\mathbf{C}\{\mathbf{n}, \mathbf{x}\}$.

3-fold lithiation of tris(p-bromophenyl)phosphine in diethyl ether is fast and essentially quantitative. Treatment with silanes $\mathbf{C}\{\mathbf{n}, \mathbf{x}\} \quad(\mathrm{n}=2,3)$ afforded the phosphines $\mathbf{D}\{\mathbf{n}, \mathbf{x}\}(\mathbf{n}=2,3)$ in high yields $(86-98 \%$, Table 3). Phosphines $\mathbf{D}\{\mathbf{1}, \mathbf{x}\}$ can al so be synthesized more efficiently following this procedure.

The advantage of using route $b$ rather than route $a$ with respect to the use of different starting materials, especially $\mathbf{C}\{\mathbf{n}, \mathbf{x}\}$ and $\mathrm{p}-\mathrm{BrC}_{6} \mathrm{H}_{4} \mathrm{X}(\mathrm{X}=\mathrm{Br}, \mathrm{I})$, becomes clear in a comparison of the overall yields of the phosphines (Table 4). The synthesis of tris[p-(trimethylsilyl)phenyl ]phosphine ( $\mathbf{D}\{\mathbf{0}\})$ by method $b$ is nearly quantitative with respect to silane (entry 2 ), in contrast to the initially reported value (35-45\%). ${ }^{20}$

All novel derivatives $\mathbf{B}-\mathbf{E}$ were characterized by their NMR spectroscopic data $\left[{ }^{1} \mathrm{H},{ }^{13} \mathrm{C},{ }^{19} \mathrm{~F},{ }^{29} \mathrm{Si}\right.$, and ${ }^{31} \mathrm{P}$ (for phosphines $\mathbf{D})$ ] and, in several cases, by their correct elemental analyses (B $\{\mathbf{2}, \mathbf{8}\}, \mathbf{B}\{\mathbf{3}, \mathbf{8}\}, \mathbf{C}\{\mathbf{2}, \mathbf{8}\}, \mathbf{D}\{\mathbf{n}, \mathbf{x}\} ; \mathrm{n}$ $=1,2,3 ; x=6,8$ ).

Interestingly, the silanes $\mathbf{B}\{\mathbf{n}, \mathbf{6}\}$ and halosilanes $\mathbf{C}$ $\{\mathbf{n}, \mathbf{6}\}(\mathrm{n}=1,2,3)$ are colorless oils, whereas extending the perfluoro chain by two $\mathrm{CF}_{2}$ units $(x=8)$ results in waxy solids for $n=2$ and 3 . Boiling and melting points of $\mathbf{C}\{\mathbf{n}, \mathbf{x}\}$ increase in order of increasing $\mathrm{n}(0<1<2<$ 3) (Table 5). Remarkably, the opposite trend is observed for the fluorous aryl phosphines $\mathbf{D}\{\mathbf{n}, \mathbf{x}\}$, with the excep- 
Table 5. Boiling and Melting Points of Compounds C and $D$

\begin{tabular}{|c|c|c|c|c|}
\hline \multirow[b]{2}{*}{ entry } & \multirow[b]{2}{*}{$n, x$} & \multicolumn{2}{|r|}{$\mathbf{C}\{\mathbf{n}, \mathbf{x}\}$} & \multirow{2}{*}{$\begin{array}{l}\mathbf{D}\{\mathbf{n}, \mathbf{x}\} \\
\mathrm{mp}\left({ }^{\circ} \mathrm{C}\right)\end{array}$} \\
\hline & & $\mathrm{mp}\left({ }^{\circ} \mathrm{C}\right)$ & $\begin{array}{c}\mathrm{bp}\left({ }^{\circ} \mathrm{C}\right) \\
\text { (pressure (mbar)) }\end{array}$ & \\
\hline 1 & $\{0\}$ & - & $51.0\left(10^{3}\right)$ & 194 (lit. 187-189) \\
\hline 2 & $\{1,6\}$ & - & $76-80(33)^{a}$ & 89 \\
\hline 3 & $\{2,6\}$ & - & $105(0.1)$ & 67 \\
\hline 4 & $\{3,6\}$ & - & $180(0.1)$ & $50-55$ \\
\hline 5 & $\{1,8\}$ & - & $106-108(33)^{a}$ & 101 \\
\hline 6 & $\{2,8\}$ & 55 & - & 72 \\
\hline 7 & $\{3,8\}$ & 93 & - & $123-125$ \\
\hline
\end{tabular}

a See ref $15 b .{ }^{b}$ See ref 21.
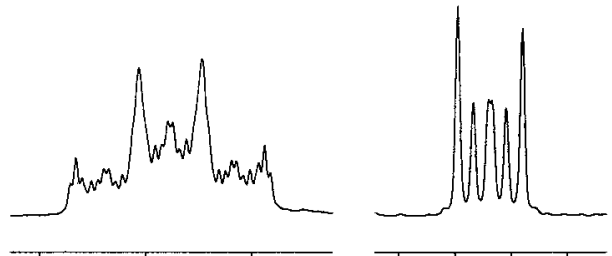

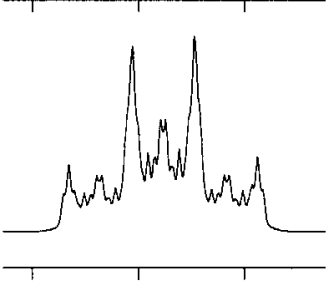

2.20

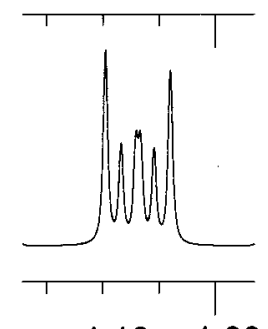

$1.10 \quad 1.00$

Figure 2. Experimental (top) and simulated (bottom) part of the ${ }^{1} \mathrm{H}$ NMR spectrum of $\mathrm{C}_{8} \mathrm{~F}_{17}\left(\mathrm{CH}_{2}\right)_{2} \mathrm{Si}(\mathrm{Me})_{2} \mathrm{Cl}(\mathbf{C}\{\mathbf{1}, \mathbf{8}\})$. Simulation parameters: $\delta_{A}, 1.07 ; \delta_{B}, 2.18$; coupling constants $(\mathrm{Hz}),{ }^{2} \mathrm{~J}_{\mathrm{A}, \mathrm{A}^{\prime}}={ }^{2} \mathrm{~J}_{\mathrm{B}, \mathrm{B}^{\prime}}=-15.3, \mathrm{3}_{\mathrm{A}, \mathrm{B}}=4.28, \mathrm{3}_{\mathrm{A}, \mathrm{B}^{\prime}}=13.1,{ }^{4} \mathrm{~J}_{\mathrm{A}, \mathrm{X}}=$ $0.36,3 \mathrm{~J}_{B, X}=18.0,5 \mathrm{~J}_{A, Y}=0.18,4_{B, Y}=1.56, \mathrm{~b}_{A, Z}=0.08,{ }^{5} \mathrm{~J}_{B, Z}$ $=0.50$.

tion of $\mathbf{D}\{\mathbf{3}, \mathbf{8}\}$, which has a melting point higher than those of all other phosphines $\mathbf{D}\{\mathbf{n}, \mathbf{x}\}$ (Table 5). Clearly, for $\mathbf{D}\{\mathbf{n}, \mathbf{x}\}$, the introduction of more or longer fluoroal kyl chains results in a decrease in the melting point despite the increase in molecular weight.

The methylene protons of the $-\mathrm{CH}_{2} \mathrm{CH}_{2} \mathrm{Si}$ - spacer group in compounds $\mathbf{B}, \mathbf{C}, \mathbf{D}$, and $\mathbf{E}(\mathrm{n}>0)$ reveal secondorder behavior in their ${ }^{1} \mathrm{H}$ NMR spectra, which, in the case of one or three fluorotails per silicon atom $(n=1$, 3), can beinterpreted as the $A A^{\prime} B B^{\prime}$ part of an $A A^{\prime} B B^{\prime} X_{2} Y_{2} Z_{2}$ spin system with characteristic ${ }^{3} \mathrm{H}, \mathrm{F}$ values $(18 \mathrm{~Hz})^{24}$ and long-range couplings up to ${ }^{5} \mathrm{H}, \mathrm{F}$ (Figure 2 ). In the case of compounds $\mathbf{B}\{\mathbf{n}, \mathbf{X}\} \quad(n=1,3)$, this pattern became visible only on selective decoupling of the $\mathrm{CH}_{2} \mathrm{Si}-\mathrm{H}$ signal.

The sizes of the observed vicinal ${ }^{3}{ }_{A B}(13.1 \mathrm{~Hz})$ and 35 ${ }_{A B}(4.3 \mathrm{~Hz})$ coupling constants are in good agreement with the time-averaged contributions calculated for the three possible rotamers ( 13.7 and $4.6 \mathrm{~Hz}$, respectively), taking into account the influence of the inductive effect of the silicon and $\mathrm{CF}_{2}$ substituents on the $\mathrm{J}_{\mathrm{H}, \mathrm{H}}$ coupling constants. ${ }^{25}$ The absence of significant changes in the spectra of $\mathbf{C}\{\mathbf{1}, \mathbf{8}\}$ upon cooling to $238 \mathrm{~K}$ and warming to $343 \mathrm{~K}$, except for small changes in line width, also corresponds to a fast exchange between the three rotamers (Figure 3).

(24) Brace, N. O. J . Org. Chem. 1971, 36, 1904.

(25) (a) Karplus, M. J . Chem. Phys. 1959, 30, 11. (b) Abraham, R. J .; Gatti, G. J . Chem. Soc. B 1969, 961. (c) Phillips, L.; Wray, V. J . Chem. Soc., Perkin Trans. 2 1972, 536.

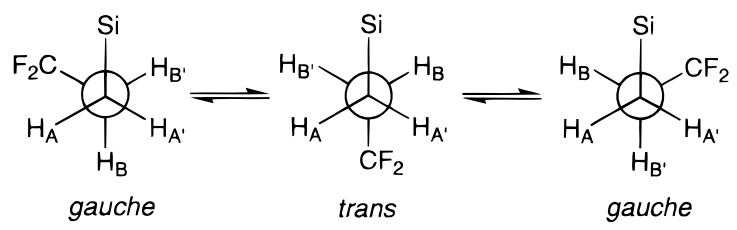

Figure 3. Equilibrium of the three rotational isomers of $\mathbf{B}$ $\{\mathbf{n}, \mathbf{x}\}, \mathbf{C}\{\mathbf{n}, \mathbf{x}\}, \mathbf{D}\{\mathbf{n}, \mathbf{x}\}$, and $\mathbf{E}\{\mathbf{n}, \mathbf{x}\}(n=1,3)$.

Table 6. Assignment of the ${ }^{19} \mathrm{Fa}$ and ${ }^{13} \mathrm{C}^{\mathrm{b}} \mathrm{NMR}$ Signals of the $\mathbf{1 H}, \mathbf{1 H}, \mathbf{2 H}, \mathbf{2 H}-$ Perfluorooctyl Chain in $\mathrm{D}\{\mathbf{1 , 6}\}$

\begin{tabular}{|c|c|c|c|}
\hline & $\delta{ }^{19} \mathrm{~F}$ & $\delta{ }^{13} \mathrm{C}[\mathrm{ppm}]$ & spin-spin coupling constants $[\mathrm{Hz}]$ \\
\hline $\mathrm{H}_{2}$ & - & 5.62 & ${ }^{1} J_{\mathrm{C}, \mathrm{H}}=121$ \\
\hline & - & $26.6(t)$ & ${ }^{2} J_{\mathrm{C}, \mathrm{F}}=23.5,{ }^{1} J_{\mathrm{C}, \mathrm{H}}=125$ \\
\hline & $-115.8(\mathrm{qm})$ & $119.3(\mathrm{tt})$ & ${ }^{1} J_{\mathrm{C}, \mathrm{F}}=-254,{ }^{2} J_{\mathrm{C}, \mathrm{F}}=30.5,{ }^{3} J_{\mathrm{H}, \mathrm{F}}=17.5,{ }^{4} J_{\mathrm{F} \alpha, \mathrm{F} \gamma} \sim 15$ \\
\hline & $-123.3(\mathrm{~m})$ & 112.3 (tquin) & ${ }^{1} J_{\mathrm{C}, \mathrm{F}}=-268,{ }^{2} J_{\mathrm{C}, \mathrm{F}}=32.0,{ }^{4} J_{\mathrm{F}, \mathrm{F}}$ not resolved \\
\hline & $-122.2(\mathrm{~m})$ & 112.1 (tquin) & ${ }^{1} J_{\mathrm{C}, \mathrm{F}}=-271,{ }^{2} J_{\mathrm{C}, \mathrm{F}}=31.8,{ }^{4} J_{\mathrm{F} \gamma, \mathrm{FE}} \sim 14$ \\
\hline & $-123.2(\mathrm{~m})$ & 111.3 (tquin) & ${ }^{1} J_{\mathrm{C}, \mathrm{F}}=-272,{ }^{2} J_{\mathrm{C}, \mathrm{F}}=31.7,{ }^{4} J_{\mathrm{F}, \mathrm{F}}$ not resolved \\
\hline & $-126.5(\mathrm{~m})$ & $109.4(\mathrm{tm})$ & ${ }^{1} J_{\mathrm{C}, \mathrm{F}}=-260,{ }^{2} J_{\mathrm{C}, \mathrm{F}}$ not resolved, ${ }^{4} J_{\mathrm{F} \gamma, \mathrm{F \varepsilon}} \sim 14$, \\
\hline $\mathrm{CF}_{3}$ & $-81.4(\mathrm{tt})$ & $118.1(\mathrm{qt})$ & ${ }^{1} J_{\mathrm{C}, \mathrm{F}}=-287,{ }^{2} J_{\mathrm{C}, \mathrm{F}}=33.3,{ }^{3} J_{\mathrm{F}, \mathrm{F}}=2.2,{ }^{4} J_{\mathrm{F}, \mathrm{F}}=9.8$ \\
\hline
\end{tabular}

a $282.4 \mathrm{MHz}, \mathrm{C}_{6} \mathrm{D}_{6}, \mathrm{~T}=25^{\circ} \mathrm{C}$. b $75.5 \mathrm{MHz}, \mathrm{C}_{6} \mathrm{D}_{6}, \mathrm{~T}=25^{\circ} \mathrm{C}$.

For compounds $\mathbf{B}\{\mathbf{2}, \mathbf{x}\}, \mathbf{C}\{\mathbf{2}, \mathbf{x}\}, \mathbf{D}\{\mathbf{2}, \mathbf{x}\}$, and $\mathbf{E}\{\mathbf{2}, \mathbf{x}\}$, the methylene protons are diastereotopic, which gives rise to more complicated $A B C D X_{2} Y_{2} Z_{2}$ spin systems in which the chemical shifts and the J ${ }_{H, H}$ and J ${ }_{H, F}$ spinspin coupling constants are different for each methylene proton.

As is demonstrated for $\mathbf{D}\{\mathbf{1}, \mathbf{6}\}$ in Table 6 , the complete assignment of the ${ }^{19} \mathrm{~F}$ resonances of $\mathbf{D}\{\mathbf{n}, \mathbf{6}\}$ with respect to the position of the fluorine atoms in the perfluoroalkyltail was made on the basis of literature information ${ }^{26}$ and data fromseveral NMR experiments $\left({ }^{13} \mathrm{C}-{ }^{19} \mathrm{~F} \mathrm{HETCOR},{ }^{13} \mathrm{C}\right.$ $\left\{{ }^{1} \mathrm{H}\right\},{ }^{13} \mathrm{C}\left\{{ }^{19} \mathrm{~F}\right\},{ }^{19} \mathrm{~F}$ COSY, ${ }^{19} \mathrm{~F}$ selective decoupling) and differsfrom that presented in somerecent publications. ${ }^{8 c, 9,16}$ $\mathrm{C}-\mathrm{F}$ correlations were made on the basis of a ${ }^{13} \mathrm{C}-{ }^{19} \mathrm{~F}$ HETCOR experiment. The $\mathrm{CF}_{3}, \alpha-\mathrm{CF}_{2}$, and $\epsilon-\mathrm{CF}_{2}$ group resonances in the ${ }^{13} \mathrm{C}\left\{{ }^{1} \mathrm{H}\right\}$ spectrum were assigned by their characteristic multiplicities. The signal of the $\epsilon-\mathrm{CF}_{2}$ group was observed as a triplet of multiplets due to ${ }^{1} \mathrm{C}, \mathrm{F}$ and slightly different ${ }^{2} \mathrm{C}, \mathrm{F}$ couplings to $\mathrm{CF}_{3}$ and $\delta$ - $\mathrm{CF}_{2}$ groups, respectively. This assignment was confirmed by selective ${ }^{19} \mathrm{~F}$ decoupling of all $\mathrm{CF}_{2}$ groups, resulting in a single ${ }^{19} \mathrm{~F}$-coupled signal of the $\epsilon-\mathrm{CF}_{2}$ group in the ${ }^{13} \mathrm{C}$ $\left\{{ }^{19} \mathrm{~F}\right\}$ spectrum (quartet due to ${ }^{2} \mathrm{C}, \mathrm{F}$ coupling with $\mathrm{CF}_{3}$ ). ${ }^{1}{ }^{19} \mathrm{~F}-{ }^{19} \mathrm{~F}$ COSY experiment, combined with the information from a ${ }^{13} \mathrm{C}-{ }^{19} \mathrm{~F}$ HETCOR spectrum, allowed the assignment of the remaining ${ }^{13} \mathrm{C}$ and ${ }^{19} \mathrm{~F}$ signals, taking into account the well-known phenomenon that $4 \mathrm{~J}, F \gg$ $3_{F, F}$ for freely rotating fluorous al iphatic chains ( $\sim 10$ and $\sim 0 \mathrm{~Hz}$, respectively). ${ }^{26}$ Also, these assignments were confirmed by selective ${ }^{19} \mathrm{~F}$ decoupling experiments.

In the case of the longer $\mathrm{C}_{8} \mathrm{~F}_{17}$ chain, the ${ }^{19} \mathrm{~F}$ resonances of the two additional $\mathrm{CF}_{2}$ moieties are not resolved from the $\gamma$-fluorine signals. However, the ${ }^{13} \mathrm{C}\left\{{ }^{19} \mathrm{~F}\right\} \mathrm{NMR}$ spectra exhibit two new signals (at $\delta 111.8$ and 111.7 for $\mathbf{D}\{\mathbf{1}, \mathbf{8}\}$ in $\left.\mathrm{C}_{6} \mathrm{D}_{6}\right)$.

The ${ }^{29} \mathrm{Si}$ NMR spectra of phosphines $\mathbf{D}\{\mathbf{n}, \mathbf{x}\}$ clearly show a deshielding of the silicon atom with an increasing

(26) (a) Mason, J . Multinuclear NMR; Plenum Publishing: New York, 1987; Chapter 16, p 443 and references therein. (b) Suhr, $\mathrm{H}$. Anwendungen der Kernmagnetischen Resonanz in der Organischen Chemie; Springer-Verlag: Berlin, 1965. 


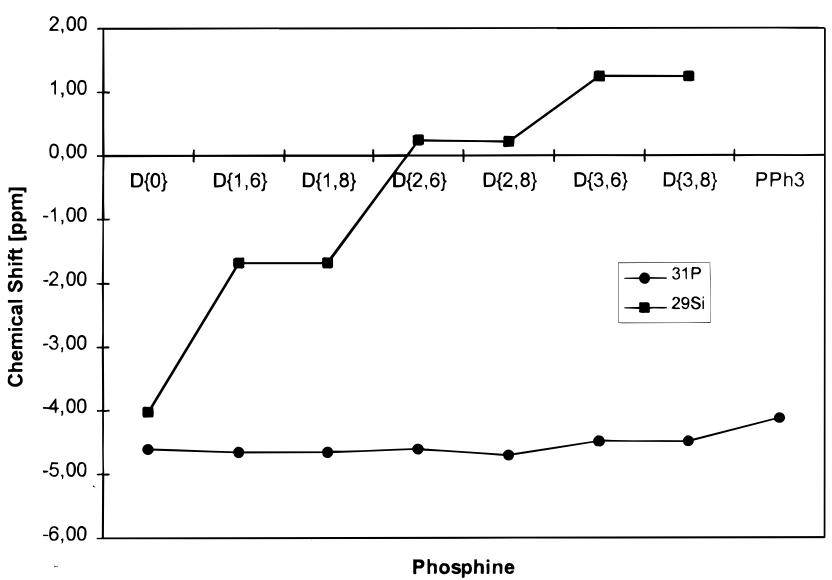

Figure 4. ${ }^{31} \mathrm{P}$ and ${ }^{29} \mathrm{Si}$ chemical shifts for the new fluorous phosphine ligands $\mathbf{D}\{\mathbf{n}, \mathbf{x}\}$ and nonfluorous $\mathbf{D}\{\mathbf{0}\}$ and $\mathrm{PPh}_{3}$. Conditions: ${ }^{31} \mathrm{P}\left\{{ }^{1} \mathrm{H}\right\} N \mathrm{NMR}, 121.5 \mathrm{MHz} ;{ }^{29} \mathrm{Si}\left\{{ }^{1} \mathrm{H}\right\} \mathrm{NMR}, 59.6$ $\mathrm{MHz}$; solvent, $\mathrm{C}_{6} \mathrm{D}_{6} / \mathrm{C}_{6} \mathrm{~F}_{6}, 1: 1(\mathrm{v} / \mathrm{v}) ; \mathrm{T}=25^{\circ} \mathrm{C}$.

Table 7. Solubilities a and Fluorous Partition Coefficients $\mathbf{P}^{\mathrm{b}}$ of the Fluorous Aryl Phosphines

\begin{tabular}{|c|c|c|c|c|c|c|c|c|}
\hline \multirow[b]{2}{*}{ compd } & \multirow{2}{*}{$\begin{array}{l}\text { F content } \\
\text { (wt \%) }\end{array}$} & \multicolumn{2}{|c|}{ n-octane } & \multicolumn{2}{|c|}{$\mathrm{c}-\mathrm{C}_{6} \mathrm{~F}_{11} \mathrm{CF}_{3}$} & \multirow[b]{2}{*}{$\mathrm{Pc}^{\mathrm{C}}$} & \multirow[b]{2}{*}{$\mathrm{Pd}^{\mathrm{d}}$} & \multirow[b]{2}{*}{ Pe } \\
\hline & & $\mathrm{mol} / \mathrm{L}$ & $\overline{g / L}$ & $\overline{\mathrm{mol} / \mathrm{L}}$ & $\overline{g / L}$ & & & \\
\hline $\mathbf{D}\{\mathbf{1}$, & 50 & 0.037 & 55 & 0.050 & 74 & 0.26 & 1.1 & 1.5 \\
\hline & & 0.008 & 14 & 0.055 & 98 & 2. & 4.6 & 2 \\
\hline$D\{2$ & 60 & 0.005 & 12 & 0.249 & 615 & 7.8 & 17 & 5. \\
\hline $\mathbf{D}\{2$ & 63 & 0.001 & 3 & 0.277 & 851 & $7 . \varepsilon$ & 28 & 9.2 \\
\hline $\mathbf{D}\{?$ & 64 & $-f$ & $-f$ & 0.162 & 502 & $4 . ?$ & 9.4 & 15 \\
\hline$D\{3,8\}$ & 67 & $0.7 \times 10^{-3}$ & 3 & 0.029 & 127 & 2.1 & 12 & 20 \\
\hline
\end{tabular}

a Expressed as the amount of phosphine that dissolves in $1 \mathrm{~L}$ of pure solvent at $25^{\circ} \mathrm{C}$. b In a 50:50 (v/v) mixture of $\mathrm{c}-\mathrm{C}_{6} \mathrm{~F}_{11} \mathrm{CF}_{3} /$ organic solvent $\left(\mathrm{P}=\mathrm{C}_{\text {fluorous phase }} / \mathrm{C}_{\text {organic phase }}\right)$ at $0{ }^{\circ} \mathrm{C}$. Derived from an analysis of each of the two phases on phosphorus by ICP-AAS, assuming that the densities of the two phases are those of the pure solvents. The estimated experimental error is less than \pm 1 in the last digit. ${ }^{\mathrm{C}} \mathrm{C}_{\mathrm{C}} \mathrm{C}_{6} \mathrm{~F}_{11} \mathrm{CF}_{3} /$ toluene, $\mathrm{T}_{\mathrm{c}}=89{ }^{\circ} \mathrm{C}$, where $\mathrm{T}_{\mathrm{c}}$ is defined as the critical temperature of the bi phasic solvent system. See, for example, ref $27 .{ }^{d} C_{C} C_{6} F_{11} C F_{3} / n$-octane, $T_{C}=42{ }^{\circ} \mathrm{C}$. ${ }^{e} \mathrm{C}-$ $\mathrm{C}_{6} \mathrm{~F}_{11} \mathrm{CF}_{3} / \mathrm{n}$-pentane, $\mathrm{T}_{\mathrm{C}} \sim 10{ }^{\circ} \mathrm{C}$. ${ }^{\mathrm{f}} \mathrm{F}$ ormation of a gel.

number of fluorotails, whereas an increase in the length of the fluorotails ( $x=6$ and 8 , respectively) has little effect (Figure 4). The opposite trend was observed for the chemical shift changes of the ${ }^{13} \mathrm{C}$ signals of the $\mathrm{CH}_{2} \mathrm{Si}$ and $\mathrm{CH}_{3} \mathrm{Si}$ moieties. However, a comparison of the ${ }^{31} \mathrm{P}$ NMR data of compounds $\mathbf{D}\{\mathbf{n}, \mathbf{x}\}, \mathbf{D}\{\mathbf{0}\}$, and $\mathrm{PPh}_{3}$ indicates clearly that the $-\mathrm{SiMe}_{3-n}\left(\mathrm{CH}_{2} \mathrm{CH}_{2}\right)_{n}$ - linker is effective in insulating the phosphorus atom from the electron-withdrawing perfluoroal kyltails. In fact, by comparison with the NMR data for $\mathbf{D}\{\mathbf{0}\}$, it can be concluded that the observed chemical shift differences between $\mathrm{PPh}_{3}$ and $\mathbf{D}\{\mathbf{n}, \mathbf{x}\}$ are predominantly due to the $\mathrm{p}$-silyl substitution (Figure 4).

Solubility and Phase Distribution Studies. As our primary objective for the perfluorotail functionalization of aryl phosphines is to use them as ligands for immobilization of phosphine-based homogeneous catalysts in fluorous solvents, ${ }^{15}$ we were interested in the solubility of fluorous aryl phosphines D in different solvents and in biphasic solvent combinations. The solubilities of the phosphines $\mathbf{D}$ in organic and fluorous solvents are listed in Table 7. It appears that the "like dissolves like" principle is valid: The fluorous phosphines have consistently higher solubilities in the fluorous solvent $\mathrm{c}-\mathrm{C}_{6} \mathrm{~F}_{11^{-}}$ $\mathrm{CF}_{3}$ than in nonfluorous n-octane. Remarkably, an optimum in the fluorocarbon solubility is observed for $n=2$

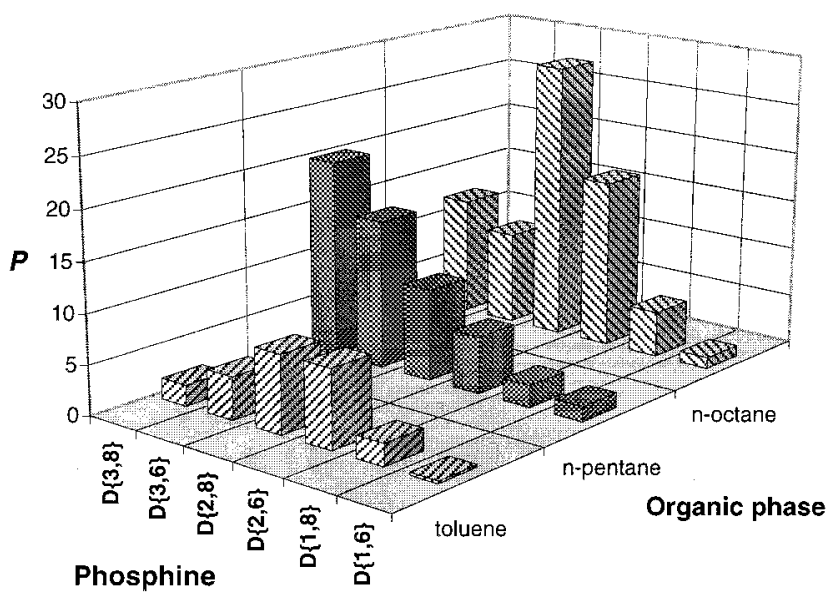

Figure 5. Plot of partition coefficients $P\left(P=C_{\text {fluorous phase }}\right.$ Corganic phase) for phosphines $\mathbf{D}\{\mathbf{n}, \mathbf{x}\}$ in several fluorous biphasic solvent systems with $\mathrm{C}_{-} \mathrm{C}_{6} \mathrm{~F}_{11} \mathrm{CF}_{3}$ as the fluorous phase at 0 ${ }^{\circ} \mathrm{C}$.

(0.25-0.28 $\mathrm{mol} / \mathrm{L})$. For $\mathrm{n}=3$, the solubility drops to values below $0.17 \mathrm{~mol} / \mathrm{L}$. The progressive decrease in fluorocarbon solubility with increasing x $(6>8>10)$ reported for fluorous trialkyl derivatives $\mathrm{P}\left(\mathrm{CH}_{2-}\right.$ $\left.\mathrm{CH}_{2} \mathrm{C}_{x} \mathrm{~F}_{2 \mathrm{x}+1}\right)_{3}{ }^{8 \mathrm{e}}$ is in contrast to the order $6<8$ observed for $\mathbf{D}\{\mathbf{n}, \mathbf{x}\}$ ( $\mathrm{n}=1$ or 2$)$. However, the reverse order (6> 8) was observed for $n=3$. It is noteworthy that the solubility of fluorous aryl phosphines $\mathbf{D}\{\mathbf{1}, \mathbf{x}\}$ in diethyl ether is significantly higher than the solubilities in n-octane, n-pentane, and c- $\mathrm{C}_{6} \mathrm{~F}_{11} \mathrm{CF}_{3}$. For example, a $>1.0$ $M$ diethyl ether solution of $\mathbf{D}\{\mathbf{1}, \mathbf{6}\}$ can be prepared, whereas a saturated n-pentane solution is ca. $0.16 \mathrm{M}$. In comparison with $\mathbf{D}\{\mathbf{0}\}$, the fluorotail-containing phosphines $\mathbf{D}\{\mathbf{1}, \mathbf{x}\}(\mathbf{x}=6,8)$ display increased $n$-pentane solubility: At a value of ca. $0.22 \mathrm{~mol} / \mathrm{L}$, the solubility of $\mathbf{D}\{\mathbf{1}, \mathbf{8}\}$ in $\mathrm{n}$-pentane is more than twice that of $\mathbf{D}\{\mathbf{0}\}$ $(<0.10 \mathrm{~mol} / \mathrm{L})$. These observations clearly indicate that the fluorous character of $\mathbf{D}\{\mathbf{1}, \mathbf{x}\}$ is not yet very pronounced, in contrast to that of the higher derivatives $\mathbf{D}$ $\{\mathbf{2}, \mathbf{X}\}$ and $\mathbf{D}\{\mathbf{3}, \mathbf{x}\}$.

For applications in fluorous biphasic catalysis and for catalyst recycling by fluorous extraction techniques, the most important feature of the fluorous aryl phosphines and derived catalytic complexes is the partition coefficient $\mathrm{P}\left(\mathrm{P}=\mathrm{C}_{\text {fluorous phase }} / \mathrm{C}_{\text {organic phase }}\right)$ in fluorous bi phasic systems. Partition coefficients of the fluorous aryl phosphines were determined in several fluorous biphasic solvent combinations (Table 7 and Figure 5) and reflect the same trend as their solubility data, i.e., there is an optimum for $\mathbf{D}\{\mathbf{2}, \mathbf{6}\}$ and $\mathbf{D}\{\mathbf{2 , 8}\}$, except for $\mathrm{c}^{-} \mathrm{C}_{6} \mathrm{~F}_{11} \mathrm{CF}_{3} /$ n-pentane for which, presumably because of the lower critical temperature $\left(T_{c}\right)$ of ca. $10{ }^{\circ} \mathrm{C}$, a steady increase of $P$ with the weight percent of fluorine was found, with a peak at $\mathbf{D}\{\mathbf{3}, \mathbf{8}\}$. The best fluorous phase affinity was found for $\mathbf{D}\{\mathbf{2}, \mathbf{8}\}$ in $\mathrm{C}-\mathrm{C}_{6} \mathrm{~F}_{11} \mathrm{CF}_{3} / \mathrm{n}$-octane $(\mathrm{P}=28)$.

In comparison with fluorous trial kyl phosphines $\mathrm{P}\left(\mathrm{CH}_{2-}\right.$ $\left.\mathrm{CH}_{2} \mathrm{C}_{8} \mathrm{~F}_{17}\right)_{3}\left(\mathrm{P}=332\right.$ in $\mathrm{C}-\mathrm{C}_{6} \mathrm{~F}_{11} \mathrm{CF}_{3} /$ toluene), ${ }^{1,, 8 e}$ relatively small partition coefficients were found for our fluorotailbearing aryl phosphine ligands (cf. $P=2.2$ for $\mathbf{D}\{\mathbf{1}, \mathbf{8}\}$ ). Consequently, there is not a simple relation between $\mathrm{P}$ and the weight percent of $\mathrm{F}$ in the phosphine; undoubtedly, there is also an effect of the partial degree of aromatic character, i.e., the number of aryl groups in the phosphine (Figure 5). 
Despite the relatively small fluorous phase affinity of the fluorous phosphine $\mathbf{D}\{\mathbf{1}, \mathbf{x}\}$, we have been able to demonstrate that rhodium leaching for $\operatorname{RhCl}[\mathbf{D}\{\mathbf{1}, \mathbf{x}\}]_{3}$ in hydrogenation catalysis can be as low as $0.1 \%{ }^{15}$ Because of their higher partition coefficients, fluorous phosphines $\mathbf{D}\{\mathbf{n}, \mathbf{x}\}$ with $n>1$, especially with $n=2$, are even more interesting for further reduction of $\mathrm{Rh}$ and phosphine leaching in fluorous biphasic catalyst separation.

\section{Conclusions}

We have demonstrated straightforward synthetic routes for the synthesis of novel, highly fluorous triarylphosphines, which are of interest for fluorous phase catalysis and catalyst recovery by fluorous bi phasic extraction. By using silicon as a branching point, it became possible to attach between three and nine perfluorotails per phosphorus atom. Through this method, phosphines containing between 50 and 67 wt \% fluorine were prepared, which reveal distinct fluorous phase affinity in fluorous biphasic solvent systems and good solubility in fluorous solvents. ${ }^{31}$ P NMR studies confirm the effective insulation of the phosphorus atom, and consequently its donor properties, from the electron-withdrawing effect of the perfluorotails. Surprisingly, the fluorous phase solubility, as well as the partition coefficients, of these particular triaryl phosphines in fluorous biphasic solvent systems displays an optimum at ca. 63 wt \% fluorine. Only in the case of $\mathrm{c}_{-} \mathrm{C}_{6} \mathrm{~F}_{11} \mathrm{CF}_{3} / \mathrm{n}$-pentane did we observe a steady increase of the fluorous phase affinity with the amount of fluorous character, resulting in an optimum for $67 \mathrm{wt}$ $\%$ fluorine. Interestingly, there is a strong correlation between the single phase fluoro- and hydrocarbon solubility of these fluorous phosphines and their fluorous phase affinity in fluorous biphasic systems.

Especially the phase partitioning of uncoordinated fluorous ligands is a particularly relevant issue for fluorous biphasic catalyst separation, as ligand dissociation is often an essential step in the catalytic cycle. Leaching of dissociated ligand into the nonfluorous phase is, therefore, a possible catalyst deactivation pathway. With this aspect in mind, we are currently further investigating fluorous catalysts based on our 6- and 9-fluorotail-containing phosphines.

\section{Experimental Section}

General Remarks. Reactions were conducted in a dinitrogen atmosphere unless noted otherwise. Solvents were obtained and prepared as follows: benzene, toluene, n-pentane, $\mathrm{n}$-hexane, and diethyl ether were distilled from $\mathrm{N}$ a/benzophe none; $\mathrm{FC}-72, \mathrm{C}^{-} \mathrm{C}_{6} \mathrm{~F}_{11} \mathrm{CF}_{3}, \mathrm{CF}_{3} \mathrm{C}_{6} \mathrm{H}_{5}$ (Acros, Alfa), $\mathrm{C}_{6} \mathrm{~F}_{6}$ (Acros), $\mathrm{C}_{6} \mathrm{D}_{6}, \mathrm{CDCl}_{3}$, and $\mathrm{n}-\mathrm{C}_{6} \mathrm{D}_{14}$ (Cambridge I sotope Laboratories, Aldrich) were degassed and stored over molecular sieves. Reagents were obtained and prepared as follows: $\mathrm{C}_{x} \mathrm{~F}_{2 x+1} \mathrm{CH}=$ $\mathrm{CH}_{2}(\mathrm{x}=6,8)$ (Acros), $\mathrm{C}_{x} \mathrm{~F}_{2 x+1} \mathrm{CH}_{2} \mathrm{CH}_{2} \mathrm{l}(\mathrm{x}=6,8)$ (Lancaster), and $\mathrm{Mg}$ turnings (Norsk Hydro, $>99.8 \%$ ) were used as received; $\mathrm{HSiCl}_{3}, \mathrm{HSi}(\mathrm{Me}) \mathrm{Cl}_{2}, \mathrm{HSiMe} C \mathrm{Cl}$, and $\mathrm{H}_{2} \mathrm{PtCl}_{6}(\mathrm{aq})$ (Acros) were stored under nitrogen and used as received. Elemental and ICP-AAS analyses were carried out by $\mathrm{H}$. Kolbe, Mikroanalytisches Laboratorium, Mühlheim an der Ruhr, Germany. ${ }^{31} \mathrm{P}$ NMR spectra were referenced relative to $85 \% \mathrm{H}_{3} \mathrm{PO}_{4}$ and ${ }^{19} \mathrm{~F} \mathrm{NMR}$ spectra relative to $\mathrm{CFCl}_{3}$ (both external). The ${ }^{19} \mathrm{~F}$ decoupler frequency in ${ }^{13} \mathrm{C}\left\{{ }^{19} \mathrm{~F}\right\} N M R$ experiments was set to either $\delta=-121$ or $\delta=-81$ to decouple from the ${ }^{19} \mathrm{~F}$ nuclei of the $\mathrm{CF}_{2}$ moieties or the $\mathrm{CF}_{3}$ group, respectively. For the simulation of ${ }^{1} \mathrm{H}$ NMR spectra, the computer program gNMR, version 3.6, Cherwell Scientific Publishing Limited, Oxford, was used.
Caution: Although the toxicity of the fluorous phosphines developed is unknown, they are lipophilic and, therefore, expected to be able to accumulate in body tissues, analogous to behavior observed for perfluorocarbons. ${ }^{28}$ Hence, proper precautions should be taken to prevent, for example, contact with the skin.

General Procedure for Reaction of the Grignard Reagents of 2-(Perfluoroalkyl)iodoethanes with Chlorosilanes. The freshly prepared and filtered $\mathrm{C}_{x} \mathrm{~F}_{2 x+1}\left(\mathrm{CH}_{2}\right)_{2} \mathrm{l}$ Grignard solution was treated with a stoichiometric amount (based on 90\% conversion of the Grignard reaction) of the respective chlorosilane and stirred overnight. The reaction mixture, which consisted of either a liquid biphasic system or a white suspension, was quenched with water $(100 \mathrm{~mL})$. After phase separation, the organic phase was combined with two 20-mL diethyl ether extracts of the water phase, and the resulting mixture was dried over $\mathrm{MgSO}_{4}$. Volatiles were removed using a rotary evaporator. The light-yellow oils (B$\{\mathbf{2}, \mathbf{6}\}, \mathbf{B}\{\mathbf{3}, \mathbf{6}\}$, and $\mathbf{B}\{\mathbf{1}, \mathbf{8}\})$ and white, waxy solids $(\mathbf{B}\{\mathbf{2}, \mathbf{8}\}$ and $\mathbf{B}\{\mathbf{3}, \mathbf{8}\}$ ) contained $\leq 10 \%$ of the Wurtz coupling product, which was removed by Kugelrohr distillation or by fractional distillation $(\mathbf{B}\{\mathbf{1}, \mathbf{6}\})$.

Methyl[bis(3,3,4,4,5,5,6,6,7,7,8,8,8-tridecafluorooctyl)]silane $(\mathbf{B}\{\mathbf{2}, \mathbf{6}\})$. A Grignard solution prepared from $12.5 \mathrm{~g}(26$ $\mathrm{mmol})$ of $\mathrm{C}_{6} \mathrm{~F}_{13}\left(\mathrm{CH}_{2}\right)_{2}$ treated with $1.24 \mathrm{~mL}(1.38 \mathrm{~g}, 12.0 \mathrm{mmol})$ of $\mathrm{HSiMeCl}_{2}$ yielded $7.68 \mathrm{~g}(10.4 \mathrm{mmol}, 79 \%$ based on $1 \mathrm{H}$,$1 \mathrm{H}, 2 \mathrm{H}, 2 \mathrm{H}$-perfluorooctyl iodide). Bp: $96^{\circ} \mathrm{C}$ (0.1 Torr). ${ }^{1 \mathrm{H}} \mathrm{NMR}$ $\left(\delta, \mathrm{CDCl}_{3}\right): 3.91$ (oct, ${ }^{1}$ s si, $\left.=187 \mathrm{~Hz},{ }^{3} \mathrm{H}, \mathrm{H}=3.8 \mathrm{~Hz}, 1 \mathrm{H}\right), 2.10$ $(\mathrm{m}, 4 \mathrm{H}), 0.90(\mathrm{~m}, 4 \mathrm{H}), 0.19\left(\mathrm{~d},{ }^{3} \mathrm{H}, \mathrm{H}=3.8 \mathrm{~Hz}, 3 \mathrm{H}\right) .{ }^{19} \mathrm{~F} N M R$ $\left(\delta, \mathrm{CDCl}_{3}\right):-82.0(\mathrm{~m}, 3 \mathrm{~F}),-117.1\left(\mathrm{~m}, \mathrm{~J}_{\mathrm{F}, \mathrm{F}}=15 \mathrm{~Hz}, 2 \mathrm{~F}\right),-123.0$ $(\mathrm{m}, 2 \mathrm{~F}),-124.0(\mathrm{~m}, 2 \mathrm{~F}),-124.5(\mathrm{~m}, 2 \mathrm{~F}),-127.3(\mathrm{~m}, 2 \mathrm{~F}) .{ }^{29}$ Si $\left\{{ }^{1} \mathrm{H}\right\} \operatorname{NMR}\left(\delta, \mathrm{CDCl}_{3}\right):-6.78 .{ }^{13} \mathrm{C}\left\{{ }^{1} \mathrm{H}\right\} \operatorname{NMR}\left(\delta, \mathrm{CDCl}_{3}\right): 26.4$ $\left(t,{ }^{2} \mathrm{~J} C, \mathrm{~F}=23 \mathrm{~Hz}\right), 2.33,-6.74$.

Bis $(3,3,4,4,5,5,6,6,7,7,8,8,9,9,10,10,10$-heptadecafluorodecyl)methylsilane (B $\{\mathbf{2}, \mathbf{8}\})$. A Grignard solution prepared from $26.2 \mathrm{~g}(45.6 \mathrm{mmol})$ of $\mathrm{C}_{8} \mathrm{~F}_{17}\left(\mathrm{CH}_{2}\right)_{2}$ treated with $2.13 \mathrm{~mL}$ $(2.36 \mathrm{~g}, 20.5 \mathrm{mmol})$ of $\mathrm{HSiMeCl}_{2}$ yielded $14.9 \mathrm{~g}(15.9 \mathrm{mmol}$, $69.7 \%$ based on $1 \mathrm{H}, 1 \mathrm{H}, 2 \mathrm{H}, 2 \mathrm{H}$-perfluoroalkyl iodide). $\mathrm{Mp}$ : $38-$ $40{ }^{\circ} \mathrm{C}$. Anal. Calcd for $\mathrm{C}_{21} \mathrm{H}_{12} \mathrm{~F}_{34} \mathrm{Si}$ : C, 26.85; $\mathrm{H}, 1.28 ; \mathrm{F}, 68.84$; $\mathrm{Si}, 2.98$. Found: $\mathrm{C}, 26.95 ; \mathrm{H}, 1.36 ; \mathrm{F}, 68.66 ; \mathrm{Si}, 2.91 .{ }^{1} \mathrm{H}$ NMR $\left(\delta, \mathrm{CDCl}_{3}\right): 3.91$ (oct, ${ }^{1}$ ) si, $\left.=191 \mathrm{~Hz},{ }^{3} \mathrm{H}, \mathrm{H}=3.6 \mathrm{~Hz}, 1 \mathrm{H}\right), 2.11$ $(\mathrm{m}, 4 \mathrm{H}), 0.91(\mathrm{~m}, 4 \mathrm{H}), 0.20\left(\mathrm{~d},{ }^{3} \mathrm{H}, \mathrm{H}=3.6 \mathrm{~Hz}, 3 \mathrm{H}\right) .{ }^{19} \mathrm{~F} \mathrm{NMR}$ $\left(\delta, \mathrm{CDCl}_{3}\right):-81.7(\mathrm{~m}, 3 \mathrm{~F}),-116.9\left(\mathrm{~m}, \mathrm{~J}_{\mathrm{F}, \mathrm{F}}=12 \mathrm{~Hz}, 2 \mathrm{~F}\right),-122.7$ $(\mathrm{m}, 6 \mathrm{~F}),-123.5(\mathrm{~m}, 2 \mathrm{~F}),-124.1(\mathrm{~m}, 2 \mathrm{~F}),-127.0(\mathrm{~m}, 2 \mathrm{~F}) .{ }^{29} \mathrm{Si}$ NMR $\left(\delta, \mathrm{CDCl}_{3}\right):-6.81\left(\mathrm{~d},{ }^{1} \mathrm{si}, \mathrm{H}=192 \mathrm{~Hz}\right) .{ }^{29} \mathrm{Si}\left\{{ }^{1} \mathrm{H}\right\} \operatorname{NMR}(\delta$, $\left.\mathrm{CDCl}_{3}\right):-6.77 .{ }^{13} \mathrm{C}\left\{{ }^{1} \mathrm{H}\right\} \mathrm{NMR}\left(\delta, \mathrm{CDCl}_{3}\right): 26.4\left(\mathrm{t},{ }^{2}\right\} \mathrm{c}, \mathrm{F}=24$ $\mathrm{Hz}), 2.26,-6.86 .{ }^{13} \mathrm{C}\left\{{ }^{19} \mathrm{~F}\right\} \mathrm{NMR}\left(\delta, \mathrm{CDCl}_{3}\right): 118.4(\mathrm{~m}), 117.5$ $\left(q,{ }^{1} \mathrm{f}_{\mathrm{C}, \mathrm{F}}=269 \mathrm{~Hz}\right), 111.7,111.5,111.2,111.1,110.6,108.8(\mathrm{q}$, 2) $\mathrm{c}, \mathrm{F}=26.3 \mathrm{~Hz}), 26.6\left(\mathrm{tm},{ }^{1} \mathrm{c} \mathrm{c}, \mathrm{H}=130 \mathrm{~Hz}\right), 2.42\left(\mathrm{tm}, \mathrm{Jj}_{\mathrm{C}, \mathrm{H}}=\right.$ $119 \mathrm{~Hz}),-7.01\left(\mathrm{qm},{ }^{1} \mathrm{c} \mathrm{c}, \mathrm{H}=121 \mathrm{~Hz}\right)$.

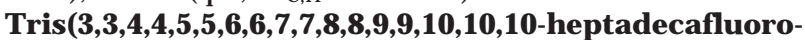
decyl)silane $(B, 3,8\})$. A Grignard solution prepared from $24.5 \mathrm{~g}(42.6 \mathrm{mmol})$ of $\mathrm{C}_{8} \mathrm{~F}_{17}\left(\mathrm{CH}_{2}\right)_{2}$ l treated with $1.08 \mathrm{~mL}(1.44$ $\mathrm{g}, 10.7 \mathrm{mmol})$ of $\mathrm{HSiCl}_{3}$ yielded $14.7 \mathrm{~g}(10.7 \mathrm{mmol}, 75 \%$ based on $1 \mathrm{H}, 1 \mathrm{H}, 2 \mathrm{H}, 2 \mathrm{H}$-perfluoroalkyl iodide). $\mathrm{Mp}: 91{ }^{\circ} \mathrm{C}$. Anal. Calcd for $\mathrm{C}_{30} \mathrm{H}_{13} \mathrm{~F}_{51} \mathrm{Si}$ : C, 26.27; $\mathrm{H}, 0.95 ; \mathrm{F}, 70.71 ; \mathrm{Si}, 2.04$. Found: C, 26.16; $\mathrm{H}, 1.10 ; \mathrm{F}, 70.62 ; \mathrm{Si}, 2.18$. ${ }^{1} \mathrm{H} \mathrm{NMR}\left(\delta ; \mathrm{CDCl}_{3} /\right.$ $\left.\mathrm{C}_{6} \mathrm{~F}_{6}, 3: 1(\mathrm{v} / \mathrm{v})\right): 3.9\left(\mathrm{~m},{ }^{1} \mathrm{~J} \mathrm{si,H}=192 \mathrm{~Hz}, 1 \mathrm{H}\right), 2.13(\mathrm{~m}, 6 \mathrm{H}), 1.05$ $(\mathrm{m}, 6 \mathrm{H}) .{ }^{19} \mathrm{~F} N M R\left(\delta ; \mathrm{CDCl}_{3} / \mathrm{C}_{6} \mathrm{~F}_{6}, 3: 1(\mathrm{v} / \mathrm{v})\right):-81.7(\mathrm{~m}, 3 \mathrm{~F})$, $-116.9(\mathrm{~m}, 2 \mathrm{~F}),-122.7(\mathrm{~m}, 6 \mathrm{~F}),-123.6(\mathrm{~m}, 2 \mathrm{~F}),-124.2(\mathrm{~m}$, $2 \mathrm{~F}),-127.0(\mathrm{~m}, 2 \mathrm{~F}) .{ }^{29} \mathrm{Si}\left\{{ }^{1} \mathrm{H}\right\} \operatorname{NMR}\left(\delta ; \mathrm{CDCl}_{3} / \mathrm{C}_{6} \mathrm{~F}_{6}, 3: 1(\mathrm{v} / \mathrm{v})\right):$ -2.38. ${ }^{13} \mathrm{C}\left\{{ }^{19} \mathrm{~F}\right\}$ NMR $\left(\delta ; \mathrm{CDCl}_{3} / \mathrm{C}_{6} \mathrm{~F}_{6}, 3: 1(\mathrm{v} / \mathrm{v})\right): 118.5(\mathrm{~m})$, $117.8\left(\mathrm{q},{ }^{1} \mathrm{~J} c, \mathrm{~F}=262 \mathrm{~Hz}\right), 111.8,111.8,111.4,111.4,110.9$, $109.0\left(\mathrm{q},{ }^{2} \mathrm{j} \mathrm{c}, \mathrm{F}=24.4 \mathrm{~Hz}\right), 26.6\left(\mathrm{tm},{ }^{1} \mathrm{c}, \mathrm{H}=130 \mathrm{~Hz}\right), 1.0(\mathrm{tm}$, 1] $\mathrm{C}, \mathrm{H}_{\mathrm{G}}=124 \mathrm{~Hz}$ ).

General Procedure for Bromination of 2-(Perfluoroalkyl)ethylsilanes $B\{\mathbf{n}, \mathbf{x}\}$. The silanes $B\{\mathbf{n}, \mathbf{x}\}$ were dissolved in either n-hexane or n-hexane/FC-72 mixtures, and a 2-fold excess of $\mathrm{Br}_{2}$ was added to the reaction mixture at $0{ }^{\circ} \mathrm{C}$. After

(27) Lo Nostro, P. Adv. Colloid Interface Sci. 1995, 56, 245-287.

(28) Lowe, K. C. In Organofluorine Chemistry, Principles and Commercial Applications; Banks, R. E., Smart, B. E., Tatlow, J . C., Eds.; Plenum Publishing: New York, 1994; Chapter 26 and references therein. 
the reaction mixture was stirred for $15 \mathrm{~h}$ at room temperature, all of the volatiles were removed in vacuo. The slightly yellow or colorless oils or waxy solids were further purified by Kugel rohr distillation, fractional distillation, or recrystallization, when necessary.

Bromo(methyl) [bis(3,3,4,4,5,5,6,6,7,7,8,8,8-tridecafluorooctyl)]silane $(\mathbf{C}\{\mathbf{2}, \mathbf{6}\})$. A solution of $25.4 \mathrm{~g}(34.3 \mathrm{mmol})$ of B $\{\mathbf{2 , 6}\}$ in $100 \mathrm{~mL}$ of $\mathrm{n}$-hexane was treated with $3.51 \mathrm{~mL}$ (11.0 $\mathrm{g}, 68.7 \mathrm{mmol})$ of $\mathrm{Br}_{2}$, yielding $27.6 \mathrm{~g}(34.0 \mathrm{mmol}, 99 \%$ based on $\mathbf{B}\{\mathbf{2 , 6 \}})$ of the title compund. Bp: $105^{\circ} \mathrm{C}\left(0.1\right.$ Torr). ${ }^{1} \mathrm{H}$ NMR $\left(\delta, \mathrm{C}_{6} \mathrm{D}_{6}\right): 1.93(\mathrm{~m}, 4 \mathrm{H}), 0.71(\mathrm{~m}, 4 \mathrm{H}), 0.02(\mathrm{~s}, 3 \mathrm{H}) .{ }^{19} \mathrm{~F} N M R$ $\left(\delta, \mathrm{C}_{6} \mathrm{D}_{6}\right):-81.5\left(\mathrm{t}, \mathrm{J}_{\mathrm{F}, \mathrm{F}}=9 \mathrm{~Hz}, 3 \mathrm{~F}\right),-115.7\left(\mathrm{~m}, \mathrm{~J}_{\mathrm{F}, \mathrm{F}}=15 \mathrm{~Hz}\right.$, $2 \mathrm{~F}),-122.3(\mathrm{~m}, 2 \mathrm{~F}),-123.3(\mathrm{~m}, 2 \mathrm{~F}),-123.5(\mathrm{~m}, 2 \mathrm{~F}),-126.6$ $(\mathrm{m}, 2 \mathrm{~F}) .{ }^{29} \mathrm{Si}\left\{{ }^{1} \mathrm{H}\right\} \operatorname{NMR}\left(\delta, \mathrm{C}_{6} \mathrm{D}_{6}\right): 29.2 .{ }^{13} \mathrm{C}\left\{{ }^{1} \mathrm{H}\right\} \operatorname{NMR}(\delta$, $\mathrm{C}_{6} \mathrm{D}_{6}$ ): $118.8\left(\mathrm{tt},{ }^{1} \mathrm{~J}_{\mathrm{C}, \mathrm{F}}=255 \mathrm{~Hz},{ }^{2} \mathrm{~J}_{\mathrm{C}, \mathrm{F}}=30.6 \mathrm{~Hz}\right.$ ), 118.1 (qt, ${ }^{1} \mathrm{C}, \mathrm{F}=289 \mathrm{~Hz}$, 2 $\mathrm{J}_{\mathrm{C}, \mathrm{F}}=33.0 \mathrm{~Hz}$ ), 112.3 (tquin, ${ }^{1} \mathrm{f}, \mathrm{F}=268 \mathrm{~Hz}$,

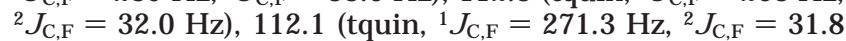
$\mathrm{Hz}$ ), 111.3 (tquin, ${ }^{1} \mathrm{~J} \mathrm{c}, \mathrm{F}=272 \mathrm{~Hz},{ }^{2} \mathrm{~J} \mathrm{c}, \mathrm{F}=31.7 \mathrm{~Hz}$ ), 109.4 (tqt, $\left.{ }^{1} \mathrm{~J} c, \mathrm{~F}=260 \mathrm{~Hz},{ }^{2} \mathrm{~J} c, \mathrm{~F}=30.5 \mathrm{~Hz}\right), 26.0\left(\mathrm{t},{ }^{2} \mathrm{~J} c, \mathrm{~F}=23.8 \mathrm{~Hz}\right), 7.73$, -0.38 .

B romo[bis $(3,3,4,4,5,5,6,6,7,7,8,8,9,9,10,10,10$-heptadecafluorodecyl)]methylsilane $\mathbf{C}\{\mathbf{2 , 8}\}$. A solution of $24.6 \mathrm{~g}$ $(26.2 \mathrm{mmol})$ of $\mathbf{B}\{\mathbf{2}, \mathbf{8}\}$ in $400 \mathrm{~mL}$ of $\mathrm{n}$-hexane was treated with $2.7 \mathrm{~mL}(8.4 \mathrm{~g}, 52 \mathrm{mmol})$ of $\mathrm{Br}_{2}$, yielding $21.3 \mathrm{~g}(20.9 \mathrm{mmol}$, $80 \%$ based on $\mathbf{B}\{\mathbf{2}, \mathbf{8}\}$ ) of the title compound after recrystallization in benzene. Mp: $55^{\circ} \mathrm{C}$. Anal. Calcd for $\mathrm{C}_{21} \mathrm{H}_{11} \mathrm{BrF}_{34} \mathrm{Si}$ : C, 24.77; $\mathrm{H}, 1.08 ; \mathrm{Br}, 7.85 ; \mathrm{F}, 63.50 ; \mathrm{Si}, 2.75$. Found: $\mathrm{C}, 24.87$; $\mathrm{H}, 1.15 ; \mathrm{Br}, 7.67 ; \mathrm{F}, 63.62 ; \mathrm{Si}, 2.69$. ${ }^{\mathrm{H}} \mathrm{H} N \mathrm{NMR}\left(\delta, \mathrm{C}_{6} \mathrm{D}_{6}\right): 2.00$ $(\mathrm{m}, 4 \mathrm{H}), 0.84(\mathrm{~m}, 4 \mathrm{H}), 0.12\left(\mathrm{~s},{ }^{2} \mathrm{si}, \mathrm{H}=6.6 \mathrm{~Hz}, 3 \mathrm{H}\right) .{ }^{19} \mathrm{~F} N M R$ $\left(\delta, \mathrm{C}_{6} \mathrm{D}_{6}\right):-81.0(\mathrm{~m}, 3 \mathrm{~F}),-115.2(\mathrm{~m}, 2 \mathrm{~F}),-121.7(\mathrm{~m}, 6 \mathrm{~F})$, $-122.5(\mathrm{~m}, 2 \mathrm{~F}),-122.9(\mathrm{~m}, 2 \mathrm{~F}),-126.0(\mathrm{~m}, 2 \mathrm{~F}) .{ }^{29} \mathrm{Si}\left\{{ }^{1} \mathrm{H}\right\} \mathrm{NMR}$ $\left(\delta, \mathrm{C}_{6} \mathrm{D}_{6}\right): 29.1 .{ }^{13} \mathrm{C}\left\{{ }^{19} \mathrm{~F}\right\} \operatorname{NMR}\left(\delta, \mathrm{C}_{6} \mathrm{D}_{6}\right): 118.7(\mathrm{~m}), 117.9$ (q, $\left.{ }^{1} \mathrm{~J}_{\mathrm{C}, \mathrm{F}}=272 \mathrm{~Hz}\right), 112.0,111.7,111.6,111.1,109.8(\mathrm{~m}), 25.9(\mathrm{tt}$, $\left.{ }^{1} \mathrm{~J}_{\mathrm{c}, \mathrm{H}}=131 \mathrm{~Hz},{ }^{2} \mathrm{~J}_{\mathrm{c}, \mathrm{H}}=5.5 \mathrm{~Hz}\right), 7.61\left(\mathrm{tm},{ }^{1} \mathrm{~J} \mathrm{c}, \mathrm{H}=122 \mathrm{~Hz}\right),-0.31$ $\left(\mathrm{qm},{ }^{1} \mathrm{~J} \mathrm{C}, \mathrm{H}=123 \mathrm{~Hz}\right)$

Bromo[tris $(3,3,4,4,5,5,6,6,7,7,8,8,9,9,10,10,10$-heptadecafluorodecyl)]silane $(\mathbf{C}\{\mathbf{3}, \mathbf{8}\})$. A biphase liquid system of $12.6 \mathrm{~g}(8.72 \mathrm{mmol})$ of $\mathbf{B}\{\mathbf{3}, \mathbf{8}\}$ in $40 \mathrm{~mL}$ of $\mathrm{FC}-72$ and $30 \mathrm{~mL}$ of n-hexane was treated with $1.0 \mathrm{~mL}(3.12 \mathrm{~g}, 19.5 \mathrm{mmol})$ of $\mathrm{Br}_{2}$, yielding $11.6 \mathrm{~g}(8.00 \mathrm{mmol}, 91.7 \%$ based on $\mathbf{B}\{\mathbf{3}, \mathbf{8}\})$ of pure C $\{3,8\} . M p: 93^{\circ} \mathrm{C}$. ${ }^{1} \mathrm{H} N M R\left(\delta ; \mathrm{C}_{6} \mathrm{D}_{6} / \mathrm{C}_{6} \mathrm{~F}_{6}, 3: 1(\mathrm{v} / \mathrm{v})\right): 2.21(\mathrm{~m}$, $6 \mathrm{H}), 1.13(\mathrm{~m}, 6 \mathrm{H}) .{ }^{19} \mathrm{~F} \mathrm{NMR}\left(\delta ; \mathrm{C}_{6} \mathrm{D}_{6} / \mathrm{C}_{6} \mathrm{~F}_{6}, 3: 1(\mathrm{v} / \mathrm{v})\right):-81.6$ $(\mathrm{m}, 3 \mathrm{~F}),-116.0(\mathrm{~m}, 2 \mathrm{~F}),-121.9(\mathrm{~m}, 6 \mathrm{~F}),-122.8(\mathrm{~m}),-123.1$ $(\mathrm{m}, 2 \mathrm{~F}),-126.3(\mathrm{~m}, 2 \mathrm{~F}) .{ }^{29} \mathrm{Si}\left\{{ }^{1} \mathrm{H}\right\}$ NMR $\left(\delta ; \mathrm{C}_{6} \mathrm{D}_{6} / \mathrm{C}_{6} \mathrm{~F}_{6}, 3: 1(\mathrm{v} /\right.$ v)): 30.1 .

1-Bromo-4-[\{ 2-(perfluoroalkyl)ethyl $\}$ dimethylsilyl]benzenes and 1-Bromo-4-(trimethylsilyl)benzene. General Procedure. $\mathrm{p}$ - $\mathrm{LiC}_{6} \mathrm{H}_{4} \mathrm{Br}$ was obtained from $\mathrm{p}$-bromoiodobenzene and 1 equiv of ${ }^{n} B u L i$ (1.5 $\mathrm{M}$ solution in $\mathrm{n}$-hexane) diluted in n-pentane at $0{ }^{\circ} \mathrm{C}$. After $1 \mathrm{~h}$, the suspension was centrifuged, and the liquid was decanted off from the white precipitate. The corresponding chlorosilane dissolved in $10 \mathrm{~mL}$ of THF was added at $-78^{\circ} \mathrm{C}$ to a suspension of $\mathrm{p}-\mathrm{LiC}_{6} \mathrm{H}_{4} \mathrm{Br}$ in $\mathrm{n}$-pentane. The reaction mixture was all owed to warm to room temperature and was stirred overnight. After the reaction was quenched with saturated $\mathrm{NH}_{4} \mathrm{Cl}(\mathrm{aq})$, the water phase was extracted with two 20-mL portions of $\mathrm{n}$-pentane. The combined organic phases were dried over $\mathrm{MgSO}_{4}$. F ractional distillation afforded the pure products. Compounds 1,4-(RM $e_{2} \mathrm{Si}_{2} \mathrm{C}_{6} \mathrm{H}_{4}(\mathrm{R}$ $\left.=\mathrm{Me},\left(\mathrm{CH}_{2}\right)_{2} \mathrm{C}_{6} \mathrm{~F}_{13},\left(\mathrm{CH}_{2}\right)_{2} \mathrm{C}_{8} \mathrm{~F}_{17}\right)$ were obtained as colorless solids.

1-B romo-4-[dimethyl $(3,3,4,4,5,5,6,6,7,7,8,8,8$-tridecafluorooctyl)silyl] benzene (E $\{\mathbf{1}, \mathbf{6}\})$. Compound $\mathbf{C}\{\mathbf{1}, \mathbf{6}\}(3.58$ $\mathrm{g}, 7.57 \mathrm{mmol})$ and $\mathrm{p}-\mathrm{LiC}_{6} \mathrm{H}_{4} \mathrm{Br}$, obtained from $2.4 \mathrm{~g}(8.48 \mathrm{mmol})$ of p-bromoiodobenzene and $5.6 \mathrm{~mL}(8.4 \mathrm{mmol})$ of ${ }^{\mathrm{n}} \mathrm{BuLi}$ solution in n-pentane $(40 \mathrm{~mL})$, yiel ded $3.53 \mathrm{~g}(6.29 \mathrm{mmol}, 83 \%$ based on $\mathbf{C}\{\mathbf{1}, \mathbf{6}\})$ of the title compound. Bp: $104{ }^{\circ} \mathrm{C}$ (0.1 Torr). ${ }^{1} \mathrm{H} N M R\left(\delta ; \mathrm{C}_{6} \mathrm{D}_{6} / \mathrm{C}_{6} \mathrm{~F}_{6}, 1: 1(\mathrm{v} / \mathrm{v})\right): 7.25(\mathrm{~m}, 2 \mathrm{H}), 7.12(\mathrm{~m}, 2 \mathrm{H})$, $2.02(\mathrm{~m}, 2 \mathrm{H}), 0.94(\mathrm{~m}, 2 \mathrm{H}), 0.22(\mathrm{~s}, 6 \mathrm{H}) .{ }^{19} \mathrm{~F} N M R\left(\delta, \mathrm{C}_{6} \mathrm{D}_{6}\right):$ $-81.4(\mathrm{~m}, 3 \mathrm{~F}),-116.4(\mathrm{~m}, 2 \mathrm{~F}),-122.5(\mathrm{~m}, 2 \mathrm{~F}),-123.5(\mathrm{~m}, 2 \mathrm{~F})$, $-123.8(\mathrm{~m}, 2 \mathrm{~F}),-126.7(\mathrm{~m}, 2 \mathrm{~F}) .{ }^{29} \mathrm{Si}\left\{{ }^{1} \mathrm{H}\right\} \mathrm{NMR}\left(\delta ; \mathrm{C}_{6} \mathrm{D}_{6} / \mathrm{C}_{6} \mathrm{~F}_{6}\right.$ $1: 1(v / v)):-1.51 .{ }^{13} \mathrm{C}\left\{{ }^{1} \mathrm{H}\right\}$ NMR $\left(\delta, \mathrm{C}_{6} \mathrm{D}_{6}\right): 136.3,135.6,131.9$, 125.0, $119.3\left(\mathrm{tt},{ }^{1} \mathrm{~J} \mathrm{C}, \mathrm{F}=255 \mathrm{~Hz}\right.$, 2 $\left.\mathrm{J}_{\mathrm{C}, \mathrm{F}}=29.8 \mathrm{~Hz}\right), 118.2(\mathrm{qt}$, 1] $\mathrm{C}, \mathrm{F}=287 \mathrm{~Hz},{ }^{2} \mathrm{~J} \mathrm{C}, \mathrm{F}^{2}=31.7 \mathrm{~Hz}$ ), 112.3 (tquin, ${ }^{1} \mathrm{~J}, \mathrm{~F}=268 \mathrm{~Hz}$ ), 112.2 (tquin, ${ }^{1} \mathrm{~J}_{\mathrm{C}, \mathrm{F}}=270 \mathrm{~Hz},{ }^{2} \mathrm{~J}_{\mathrm{C}, \mathrm{F}}=32.5 \mathrm{~Hz}$ ), 111.3 (tquin,
1] $\left.\mathrm{C}, \mathrm{F}=274 \mathrm{~Hz},{ }^{2} \mathrm{~J}_{\mathrm{C}, \mathrm{F}}=31.6 \mathrm{~Hz}\right), 109.5$ (tqt, ${ }^{1} \mathrm{~J}_{\mathrm{c}, \mathrm{F}}=270 \mathrm{~Hz}$, 2) $\mathrm{C,F}=31.6 \mathrm{~Hz}), 26.5\left(\mathrm{t},{ }^{2} \mathrm{~J} \mathrm{C,F}=23.7 \mathrm{~Hz}\right), 5.56\left(\mathrm{~s},{ }^{1} \mathrm{~J} \mathrm{c}, \mathrm{Si}=50.5\right.$ $\mathrm{Hz}),-3.65\left(\mathrm{~s},{ }^{1} \mathrm{~J} \mathrm{c}, \mathrm{Si}=52.8 \mathrm{~Hz}\right)$.

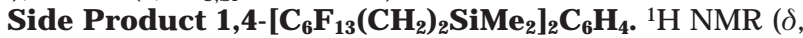
$\left.\mathrm{CDCl}_{3}\right): 7.34(\mathrm{~s}, 4 \mathrm{H}), 2.02(\mathrm{~m}, 4 \mathrm{H}), 0.74(\mathrm{~m}, 4 \mathrm{H}), 0.11(\mathrm{~s}, 12 \mathrm{H}$, $\left.{ }^{2} \mathrm{si,H}=6.6 \mathrm{~Hz}\right) .{ }^{13} \mathrm{C}\left\{{ }^{1} \mathrm{H}\right\} \mathrm{NMR}\left(\delta, \mathrm{C}_{6} \mathrm{D}_{6}\right): 139.0,133.6,26.6(\mathrm{t}$, 2) $\mathrm{c}, \mathrm{F}=24.2 \mathrm{~Hz}), 5.66\left(\mathrm{t},{ }^{3} \mathrm{~J} \mathrm{c}, \mathrm{F}=2.1 \mathrm{~Hz}\right),-3.34\left(\mathrm{~s},{ }^{1} \mathrm{~J} \mathrm{c}, \mathrm{Si}=60.5\right.$ $\mathrm{Hz}$ ).

1-Bromo-4-[3,3,4,4,5,5,6,6,7,7,8,8,9,9,10,10,10-heptadecafluorodecyl (dimethyl)silyl]benzene (E $\{1,8\})$. Compound C $\{\mathbf{1}, \mathbf{8}\}(21.9 \mathrm{~g}, 40.5 \mathrm{mmol})$ and $\mathrm{p}-\mathrm{LiC}_{6} \mathrm{H}_{4} \mathrm{Br}$, obtained from 12.6 $\mathrm{g}(44.5 \mathrm{mmol})$ of p-bromoiodobenzene and $27 \mathrm{~mL}(40.5 \mathrm{mmol})$ of ${ }^{n}$ BuLi solution in n-pentane $(80 \mathrm{~mL})$, yielded $23.3 \mathrm{~g}(35.2$ $\mathrm{mmol}, 87 \%$ based on $\mathbf{C}\{\mathbf{1}, \mathbf{8}\})$ of the title compound. Bp: $145-$ $150^{\circ} \mathrm{C}(0.1 \mathrm{Torr}) . \mathrm{Mp}: 38^{\circ} \mathrm{C} .{ }^{1} \mathrm{H}$ NMR $\left(\delta, \mathrm{C}_{6} \mathrm{D}_{6}\right): 7.31(\mathrm{~m}, 2 \mathrm{H})$, $6.89(\mathrm{~m}, 2 \mathrm{H}), 1.84(\mathrm{~m}, 2 \mathrm{H}), 0.75(\mathrm{~m}, 2 \mathrm{H}),-0.06\left(\mathrm{~s}, 6 \mathrm{H},{ }^{2} \mathrm{~J} \mathrm{si,H}=\right.$ $6.4 \mathrm{~Hz}) .{ }^{13} \mathrm{C}\left\{{ }^{1} \mathrm{H}\right\} \operatorname{NMR}\left(\delta, \mathrm{C}_{6} \mathrm{D}_{6}\right): 136.3,135.6,131.9,125.0$, $119.3\left(\mathrm{tt},{ }^{1} \mathrm{~J} \mathrm{C}, \mathrm{F}=254 \mathrm{~Hz},{ }^{2} \mathrm{~J} \mathrm{C}, \mathrm{F}=31.1 \mathrm{~Hz}\right.$ ), 118.0 (qt, ${ }^{1} \mathrm{~J} \mathrm{c}, \mathrm{F}=$ $288 \mathrm{~Hz}$, 2J $\mathrm{c}, \mathrm{F}=33.0 \mathrm{~Hz}), 112.7,112.7,111.9,111.9(\mathrm{tm}), 111.2$ (tm), 109.1 (tm), $26.5\left(\mathrm{t},{ }^{2} \mathrm{~J} \mathrm{c}, \mathrm{F}=23.8 \mathrm{~Hz}\right), 5.56\left(\mathrm{~s},{ }^{1} \mathrm{~J} \mathrm{c}, \mathrm{Si}=50.7\right.$ $\mathrm{Hz}),-3.65\left(\mathrm{~s},{ }^{1} \mathrm{~J} c, \mathrm{Si}=53.1 \mathrm{~Hz}\right)$.

Side Product $\mathbf{1 , 4}-\left[\mathbf{C}_{8} \mathbf{F}_{17}\left(\mathbf{C H}_{2}\right)_{2} \mathrm{SiMe}_{2}\right]_{2} \mathbf{C}_{6} \mathbf{H}_{4} \cdot{ }^{1} \mathrm{H}$ NMR $(\delta$, $\left.\mathrm{CDCl}_{3}\right): 7.48(\mathrm{~s}, 4 \mathrm{H}), 1.99(\mathrm{~m}, 4 \mathrm{H}), 0.96(\mathrm{~m}, 4 \mathrm{H}), 0.31(\mathrm{~s}, 12 \mathrm{H})$.

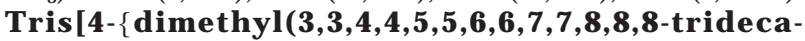
fluorooctyl)silyl $\}$ phenyl]phosphine $(D\{1,6\})$ through Route a. Compound $\mathbf{E}\{\mathbf{1}, \mathbf{6}\}(6.1 \mathrm{~g}, 11 \mathrm{mmol})$ in $50 \mathrm{~mL}$ of n-hexane was treated with $14.5 \mathrm{~mL}(21.7 \mathrm{mmol})$ of tBuLi (1.50 $\mathrm{M}$ solution in $\mathrm{n}$-hexane) at $-78^{\circ} \mathrm{C}$. The reaction mixture was allowed to reach room temperature and then stirred for $15 \mathrm{~h}$. The white precipitate formed was washed with n-pentane ( 2 $\times 20 \mathrm{~mL})$ and suspended in di ethyl ether $(50 \mathrm{~mL})$. Solids were removed by centrifuge, and the clear solution was evaporated to dryness, affording $4.89 \mathrm{~g}$ of the lithiated aryl compound, which contained 1 equiv of diethyl ether ( ${ }^{1} \mathrm{H}$ NMR). This material $(4.19 \mathrm{~g})$ in a mixture of $n$-hexane $(30 \mathrm{~mL})$ and THF $(5 \mathrm{~mL})$ was treated with $\mathrm{PCl}_{3}(0.25 \mathrm{~mL}, 2.84 \mathrm{mmol})$ in n-hexane $(5 \mathrm{~mL})$ at $-78^{\circ} \mathrm{C}$. After $1 \mathrm{~h}$, the reaction mixture was allowed to warm to room temperature and stirred for another $15 \mathrm{~h}$. Volatiles were removed in vacuo after filtration, and the white residue was extracted with $n$-pentane $(3 \times 20 \mathrm{~mL})$. The volume of the combined n-pentane phases was reduced to $10 \mathrm{~mL}$, and the extract was stored at $-10{ }^{\circ} \mathrm{C}$. The mother liquor was decanted, and the white precipitate was dried in vacuo. Yield: $2.85 \mathrm{~g}(1.93 \mathrm{mmol}, 62 \%$ based on $\mathbf{E}\{\mathbf{1}, 6\}) . \mathrm{Mp}: 89^{\circ} \mathrm{C}$. Anal. Calcd for $\mathrm{C}_{48} \mathrm{H}_{42} \mathrm{~F}_{39} \mathrm{Si}_{3} \mathrm{P}$ : C, 39.1; H, 2.85; F, 50.3; Si, 5.71; P, 2.10. Found: C, 39.3; H, 2.87; F, 50.1; Si, 5.80; P, 2.08. ${ }^{1} \mathrm{H}$ NMR $\left(\delta ; \mathrm{C}_{6} \mathrm{D}_{6} / \mathrm{C}_{6} \mathrm{~F}_{6}, 1: 1(\mathrm{v} / \mathrm{v})\right): 7.33(\mathrm{~m}, 2 \mathrm{H}), 7.25(\mathrm{~m}, 2 \mathrm{H})$, $2.04(\mathrm{~m}, 2 \mathrm{H}), 0.97(\mathrm{~m}, 2 \mathrm{H}), 0.26(\mathrm{~s}, 6 \mathrm{H}) .{ }^{31} \mathrm{P}\left\{{ }^{1} \mathrm{H}\right\} \mathrm{NMR}\left(\delta ; \mathrm{C}_{6} \mathrm{D}_{6}\right)$ $\left.\mathrm{C}_{6} \mathrm{~F}_{6}, 1: 1(\mathrm{v} / \mathrm{v})\right):-4.66 .{ }^{29} \mathrm{Si}\left\{{ }^{1} \mathrm{H}\right\} \operatorname{NMR}\left(\delta ; \mathrm{C}_{6} \mathrm{D}_{6} / \mathrm{C}_{6} \mathrm{~F}_{6}, 1: 1(\mathrm{v} /\right.$ v)): $-1.69 .{ }^{19} \mathrm{~F} N M R\left(\delta, \mathrm{C}_{6} \mathrm{D}_{6}\right):-81.4\left(\mathrm{tt}, \mathrm{J}_{\mathrm{F}, \mathrm{F}}=9.7 \mathrm{~Hz}, \mathrm{~J}_{\mathrm{F}, \mathrm{F}}=\right.$ $2.5 \mathrm{~Hz}, 3 \mathrm{~F}),-115.8(\mathrm{~m}, 2 \mathrm{~F}),-122.2(\mathrm{~m}, 2 \mathrm{~F}),-123.2(\mathrm{~m}, 2 \mathrm{~F})$, $-123.3(\mathrm{~m}, 2 \mathrm{~F}),-126.5(\mathrm{~m}, 2 \mathrm{~F}) .{ }^{13} \mathrm{C}\left\{{ }^{1} \mathrm{H}\right\} \mathrm{NMR}\left(\delta, \mathrm{C}_{6} \mathrm{D}_{6}\right): 139.4$ $\left.(d,]_{p, C}=12.7 \mathrm{~Hz}\right), 138.7\left(\mathrm{~J} \mathrm{Si,C}_{\mathrm{Si}}=65 \mathrm{~Hz}\right), 134.3\left(\mathrm{~d}\right.$, 3 $\mathrm{J}_{\mathrm{P}, \mathrm{C}}=6.7$ $\mathrm{Hz}), 134.1\left(\mathrm{~d},{ }^{2} \mathrm{~J}\right.$ P, , $\left.=18.9 \mathrm{~Hz}\right), 119.3\left(\mathrm{tt},{ }^{1} \mathrm{~J} \mathrm{c}, \mathrm{F}=254 \mathrm{~Hz},{ }^{2} \mathrm{~J} c, F\right.$ $=30.5 \mathrm{~Hz}$ ), 118.1 (qt, J $\mathrm{c}, \mathrm{F}=289 \mathrm{~Hz}, \mathrm{~J}_{\mathrm{C}, \mathrm{F}}=33.3 \mathrm{~Hz}$ ), 112.3 (tquin, 1 $\mathrm{c}_{\mathrm{C}, \mathrm{F}}=268 \mathrm{~Hz}$, 2 $\mathrm{J}_{\mathrm{C}, \mathrm{F}}=32.0 \mathrm{~Hz}$ ), 112.1 (tquin, 1 $\mathrm{J}_{\mathrm{C}, \mathrm{F}}=$ $271 \mathrm{~Hz}$, 2J ${ }_{\mathrm{C}, \mathrm{F}}=31.8 \mathrm{~Hz}$ ), 111.3 (tquin, ${ }^{1} \mathrm{~J}_{\mathrm{C}, \mathrm{F}}=272 \mathrm{~Hz}$, ${ }^{2} \mathrm{~J}_{\mathrm{C}, \mathrm{F}}=$ 31.7 Hz), 109.4 (tqt, ${ }^{1} \mathrm{~J} \mathrm{c}, \mathrm{F}=260 \mathrm{~Hz},{ }^{2} \mathrm{~J} \mathrm{c}, \mathrm{F}=30.5 \mathrm{~Hz}$ ), 26.6 (t, 2] $\mathrm{c}, \mathrm{F}=23.5 \mathrm{~Hz}), 5.62\left(\mathrm{~s},{ }^{1} \mathrm{~J} \mathrm{c}, \mathrm{Si}=50.9 \mathrm{~Hz}\right),-3.51\left(\mathrm{~s},{ }^{1} \mathrm{c}, \mathrm{Si}=\right.$ $53.1 \mathrm{~Hz}) .{ }^{13} \mathrm{C}\left\{{ }^{19} \mathrm{~F}\right\} \operatorname{NMR}\left(\delta, \mathrm{C}_{6} \mathrm{D}_{6}\right): 139.4\left(\mathrm{dt},{ }^{1} \mathrm{~J}, \mathrm{C}=12.8 \mathrm{~Hz}\right)$, 138.6, $134.2(\mathrm{dm}), 119.3(\mathrm{~s}), 118.1\left(\mathrm{q},{ }^{1} \mathrm{~J} \mathrm{c}, \mathrm{F}=269 \mathrm{~Hz}\right), 112.3$, $112.1,111.3,109.5\left(\mathrm{q},{ }^{2} \mathrm{~J} \mathrm{c}, \mathrm{F}=25.1 \mathrm{~Hz}\right), 26.6\left(\mathrm{tm},{ }^{1} \mathrm{~J} \mathrm{c}, \mathrm{H}=125\right.$ $\mathrm{Hz}), 5.57\left(\mathrm{t}, \mathrm{J}_{\mathrm{c}, \mathrm{H}}=121 \mathrm{~Hz}\right), 4.34\left(\mathrm{q},{ }^{1} \mathrm{~J}_{\mathrm{c}, \mathrm{H}}=121 \mathrm{~Hz}\right)$.

Tris $[4-\{(3,3,4,4,5,5,6,6,7,7,8,8,9,9,10,10,10$-heptadecafluorodecyl)dimethylsilyl\} phenyl]phosphine (D $\{1,8\})$ through Route a. A solution of $4.36 \mathrm{~g}(6.59 \mathrm{mmol})$ of $\mathbf{E}\{\mathbf{1}, \mathbf{8}\}$ in $30 \mathrm{~mL}$ of $\mathrm{n}$-hexane was treated with $4.39 \mathrm{~mL}(6.58 \mathrm{mmol})$ of ${ }^{\mathrm{n}} \mathrm{BuLi}$ solution at $0{ }^{\circ} \mathrm{C}$ and stirred for $15 \mathrm{~h}$ at room temperature. The voluminous white precipitate that separated was washed with $\mathrm{n}$-hexane $(20 \mathrm{~mL})$ and dried in vacuo to afford $2.74 \mathrm{~g}$ of lithiated product. Alternatively, $9.28 \mathrm{~g}$ (14.0 $\mathrm{mmol})$ of $\mathbf{E}\{\mathbf{1}, \mathbf{8}\}$ in $50 \mathrm{~mL}$ of $\mathrm{n}$-hexane and $18.7 \mathrm{~mL}$ (28.1 $\mathrm{mmol}$ ) of ${ }^{\mathrm{B}} \mathrm{BuLi}$ solution at $-78{ }^{\circ} \mathrm{C}$ afforded, through a similar workup, $7.07 \mathrm{~g}$ of a 1:1 mixture of the lithiated aryl compound and $\mathrm{LiBr}$. Lithiated $\mathbf{E}\{\mathbf{1}, \mathbf{8}\}(2.74 \mathrm{~g}, 4.65 \mathrm{mmol})$ in a mixture 
of n-hexane $(30 \mathrm{~mL})$ and THF $(5 \mathrm{~mL})$ was treated with 0.135 $\mathrm{mL}(1.55 \mathrm{mmol})$ of $\mathrm{PCl}_{3}$ in $\mathrm{n}$-hexane $(5 \mathrm{~mL})$ at $-78{ }^{\circ} \mathrm{C}$. A workup similar to that for $\mathbf{D}\{\mathbf{1}, \mathbf{6}\}$ yielded $1.59 \mathrm{~g}$ of $\mathbf{D}\{\mathbf{1}, \mathbf{8}\}(0.89$ $\mathrm{mmol}, 41 \%$ based on $\mathbf{E}\{\mathbf{1}, \mathbf{8}\})$. Alternatively, $7.07 \mathrm{~g}$ of the $1: 1$ mixture of lithiated $\mathbf{E}\{\mathbf{1}, \mathbf{8}\}$ and $\mathrm{LiBr}$ was suspended in n-pentane $(100 \mathrm{~mL})$ and treated with $\mathrm{P}(\mathrm{OMe})_{3}(0.41 \mathrm{~mL}, 3.48$ $\mathrm{mmol})$ at $0{ }^{\circ} \mathrm{C}$, yielding $4.00 \mathrm{~g}$ of $\mathbf{D}\{\mathbf{1}, 8\}(2.25 \mathrm{mmol}, 48 \%$ based on $E\{\mathbf{1 , 8}\})$, through a workup procedure similar to that for D $\{\mathbf{1 , 6}\}$. M p: $101{ }^{\circ} \mathrm{C}$. Anal. Calcd for $\mathrm{C}_{54} \mathrm{H}_{42} \mathrm{~F}_{51} \mathrm{Si}_{3} \mathrm{P}: \mathrm{C}, 36.52$; $\mathrm{H}$, 2.34; F, 54.6; Si, 4.74; P, 1.75. Found: C, 36.6; H, 2.41; F, 54.4; $\mathrm{Si}, 4.85 ; \mathrm{P}, 1.86$. ${ }^{1 \mathrm{H}} \mathrm{NMR}\left(\delta ; \mathrm{C}_{6} \mathrm{D}_{6} / \mathrm{C}_{6} \mathrm{~F}_{6}, 1: 1(\mathrm{v} / \mathrm{v})\right): 7.34$ $(\mathrm{m}, 2 \mathrm{H}), 7.25(\mathrm{~m}, 2 \mathrm{H}), 2.04(\mathrm{~m}, 2 \mathrm{H}), 0.98(\mathrm{~m}, 2 \mathrm{H}), 0.27(\mathrm{~s}, 6 \mathrm{H})$. ${ }^{31} \mathrm{P}\left\{{ }^{1} \mathrm{H}\right\} N M R\left(\delta ; \mathrm{C}_{6} \mathrm{D}_{6} / \mathrm{C}_{6} \mathrm{~F}_{6}, 1: 1(\mathrm{v} / \mathrm{v})\right):-4.67 .{ }^{29} \mathrm{Si}\left\{{ }^{1} \mathrm{H}\right\} N M R$ $\left(\delta ; \mathrm{C}_{6} \mathrm{D}_{6} / \mathrm{C}_{6} \mathrm{~F}_{6}, 1: 1(\mathrm{v} / \mathrm{v})\right):-1.69 .{ }^{13} \mathrm{C}\left\{{ }^{19} \mathrm{~F}\right\}\left(\delta, \mathrm{C}_{6} \mathrm{D}_{6}\right): 139.4(\mathrm{dt}$, 1 $\left.\mathrm{P}, \mathrm{C}=12.7 \mathrm{~Hz},{ }^{2} \mathrm{~J} \mathrm{C}, \mathrm{H}=6.1 \mathrm{~Hz}\right), 138.6(\mathrm{~m}), 134.3(\mathrm{dm}), 134.1$ (dm), $119.3(\mathrm{~m}), 118.1$ (q, ${ }^{1} \mathrm{c}$ c,F $\left.=268 \mathrm{~Hz}\right), 112.3,112.2,111.8$, 111.7, 111.1, $109.3\left(\mathrm{qm},{ }^{2} \mathrm{~J} \mathrm{c}_{\mathrm{F}}=26 \mathrm{~Hz}\right), 26.5\left(\mathrm{tt},{ }^{1} \mathrm{~J}_{\mathrm{c}, \mathrm{H}}=129\right.$ $\mathrm{Hz}$, $\left.{ }^{2} \mathrm{~J}_{\mathrm{F}, \mathrm{F}}=5.5 \mathrm{~Hz}\right), 5.58\left(\mathrm{t}, \mathrm{l}_{\mathrm{C}, \mathrm{H}}=121 \mathrm{~Hz}\right),-3.51\left(\mathrm{q},{ }^{1} \mathrm{~J} \mathrm{c}, \mathrm{H}=\right.$ $119 \mathrm{~Hz}) .{ }^{19} \mathrm{~F} N M R\left(\delta, \mathrm{C}_{6} \mathrm{D}_{6}\right):-81.4(\mathrm{~m}, 3 \mathrm{~F}),-116.7(\mathrm{~m}, 2 \mathrm{~F})$, $-122.2(\mathrm{~m}, 6 \mathrm{~F}),-123.0(\mathrm{~m}, 2 \mathrm{~F}),-123.7(\mathrm{~m}, 2 \mathrm{~F}),-126.8(\mathrm{~m}$, 2F).

Tris[4-\{(2-((perfluoroalkyl)ethyl)silyl \}phenyl]phosphines $(D\{n, x\})$ through Route $b$. General Procedure. $\mathrm{P}\left(\mathrm{C}_{6} \mathrm{H}_{4}-\mathrm{p}-\mathrm{Br}\right)_{3}$ was dissolved in diethyl ether and treated with 6 equiv of tBuLi ( $1.5 \mathrm{M}$ in n-hexane) at $-78^{\circ} \mathrm{C}$. After $10 \mathrm{~min}$, when a voluminous white precipitate had formed, a solution of the fluorous bromosilane $\mathbf{C}\{\mathbf{n}, \mathbf{x}\}$ in diethyl ether was added. The reaction mixture was allowed to reach room temperature and was stirred for another $15 \mathrm{~h}$. In case the phosphines did not precipitate quantitatively, the reaction mixture was filtered, and the product was dried in vacuo. All volatiles of the filtrate were removed in vacuo, and the residue was extracted in $50 \mathrm{~mL}$ of FC-72. The remainder of the product was isolated from the filtrate by removal of the volatiles in vacuo. Minor amounts of impurities were removed by washing with npentane.

Tris[4- di methyl $(3,3,4,4,5,5,6,6,7,7,8,8,8-t r i d e c a-$ fluorooctyl)silyl $\}$ phenyl]phosphine $(D\{1,6\})$. Compound C $\{\mathbf{1 , 6}\}(6.09 \mathrm{~g}, 13.8 \mathrm{mmol})$ added to a suspension of $\mathrm{P}\left(\mathrm{C}_{6} \mathrm{H}_{4-}\right.$ $\mathrm{p}-\mathrm{Li})_{3}$, obtained from $2.30 \mathrm{~g}(4.61 \mathrm{mmol})$ of $\mathrm{P}\left(\mathrm{C}_{6} \mathrm{H}_{4}-\mathrm{p}-\mathrm{Br}\right)_{3}$ in $50 \mathrm{~mL}$ of hexane/diethyl ether $(3: 1, \mathrm{v} / \mathrm{v})$ and $18.4 \mathrm{~mL}(27.7$ $\mathrm{mmol})$ of tBuLi solution, yielded $5.23 \mathrm{~g}(3.53 \mathrm{mmol}, 77 \%$ based on $\mathbf{C}\{\mathbf{1}, \mathbf{6}\}$ ) of the title compound, after quenching of the reaction with degassed water $(20 \mathrm{~mL})$, phase separation, and extraction with diethyl ether $(30 \mathrm{~mL})$.

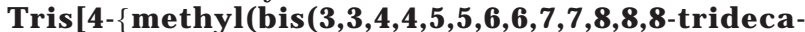
fluorooctyl))silyl $\}$ phenyl]phosphine $(D\{2,6\})$. Compound C $\{\mathbf{2}, \mathbf{6}\}(9.43 \mathrm{~g}, 11.6 \mathrm{mmol})$ in $150 \mathrm{~mL}$ of diethyl ether added to a suspension of $\mathrm{P}\left(\mathrm{C}_{6} \mathrm{H}_{4}-\mathrm{p}-\mathrm{Li}\right)_{3}$, obtained from $2.09 \mathrm{~g}(4.19$ $\mathrm{mmol})$ of $\mathrm{P}\left(\mathrm{C}_{6} \mathrm{H}_{4}-\mathrm{p}-\mathrm{Br}\right)_{3}$ in $100 \mathrm{~mL}$ of diethyl ether and 16.6 $\mathrm{mL}(24.9 \mathrm{mmol})$ of tBuLi solution, yielded $9.37 \mathrm{~g}(3.79 \mathrm{mmol}$, $98 \%$ based on $\mathbf{C}\{\mathbf{2}, \mathbf{6}\})$ of the title compound. $\mathrm{Mp}: 67^{\circ} \mathrm{C}$. Anal. Calcd for $\mathrm{C}_{69} \mathrm{H}_{45} \mathrm{~F}_{78} \mathrm{Si}_{3} \mathrm{P}$ : C, 33.50; H, 1.82; F, 59.97; Si, 3.40; P, 1.25. Found: C, 33.64; H, 1.95; F, 60.11; Si, 3.32; P, 1.22 ${ }^{1} \mathrm{H} N M R\left(\delta ; \mathrm{C}_{6} \mathrm{D}_{6} / \mathrm{C}_{6} \mathrm{~F}_{6}, 1: 1(\mathrm{v} / \mathrm{v})\right): 7.32(\mathrm{~m}, 6 \mathrm{H}), 7.28(\mathrm{~m}, 6 \mathrm{H})$, $2.02(\mathrm{~m}, 12 \mathrm{H}), 1.01(\mathrm{~m}, 12 \mathrm{H}), 0.24(\mathrm{~s}, 9 \mathrm{H}) .{ }^{31} \mathrm{P}\left\{{ }^{1} \mathrm{H}\right\} \operatorname{NMR}(\delta ;$ $\left.\mathrm{C}_{6} \mathrm{D}_{6} / \mathrm{C}_{6} \mathrm{~F}_{6}, 1: 1(\mathrm{v} / \mathrm{v})\right):-4.62 .{ }^{29} \mathrm{Si}\left\{{ }^{1} \mathrm{H}\right\} \operatorname{NMR}\left(\delta ; \mathrm{C}_{6} \mathrm{D}_{6} / \mathrm{C}_{6} \mathrm{~F}_{6}, 1: 1\right.$ $(\mathrm{v} / \mathrm{v})): 0.24 .{ }^{19} \mathrm{~F}$ NMR $\left(\delta ; \mathrm{C}_{6} \mathrm{D}_{6} / \mathrm{C}_{6} \mathrm{~F}_{6}, 1: 1(\mathrm{v} / \mathrm{v})\right):-81.5(\mathrm{~m}, 3 \mathrm{~F})$, $-116.0(\mathrm{~m}, 2 \mathrm{~F}),-122.0(\mathrm{~m}, 2 \mathrm{~F}),-123.0(\mathrm{~m}, 2 \mathrm{~F}),-123.3(\mathrm{~m}$, $2 \mathrm{~F}),-126.4(\mathrm{~m}, 2 \mathrm{~F}) .{ }^{13} \mathrm{C}\left\{{ }^{1} \mathrm{H}\right\} \operatorname{NMR}\left(\delta ; \mathrm{C}_{6} \mathrm{D}_{6} / \mathrm{C}_{6} \mathrm{~F}_{6}, 1: 1(\mathrm{v} / \mathrm{v})\right)$ : $139.0(\mathrm{~m}), 138.3,134.4(\mathrm{dm}), 119.4(\mathrm{~s}), 118.5\left(\mathrm{q},{ }^{1} \mathrm{~J} \mathrm{c}, \mathrm{F}=271\right.$ $\mathrm{Hz}), 112.6,112.5,111.7,109.9,26.6\left(\mathrm{tm},{ }^{1} \mathrm{~J} \mathrm{c}, \mathrm{H}=130 \mathrm{~Hz}\right), 4.06$ $\left(t, 1_{\mathrm{C}, \mathrm{H}}=120 \mathrm{~Hz}\right),-6.45\left(\mathrm{q},{ }_{\mathrm{J}} \mathrm{C}, \mathrm{H}=120 \mathrm{~Hz}\right)$.

Tris[4-\{tris(3,3,4,4,5,5,6,6,7,7,8,8,8-tridecafluorooctyl)silyl $\}$ phenyl]phosphine ( $\mathbf{D}\{\mathbf{3}, \mathbf{6}\})$. Compound $\mathbf{C}\{\mathbf{3}, \mathbf{6}\}(16.4$ $\mathrm{g}, 14.3 \mathrm{mmol}$ ) in $100 \mathrm{~mL}$ of diethyl ether added to a suspension of $\mathrm{P}\left(\mathrm{C}_{6} \mathrm{H}_{4}-\mathrm{p}-\mathrm{Li}\right)_{3}$, obtained from $2.38 \mathrm{~g}(4.77 \mathrm{mmol})$ of $\mathrm{P}\left(\mathrm{C}_{6} \mathrm{H}_{4}-\right.$ $\mathrm{p}-\mathrm{Br})_{3}$ in $100 \mathrm{~mL}$ of diethyl ether and $19.1 \mathrm{~mL}(28.6 \mathrm{mmol})$ of

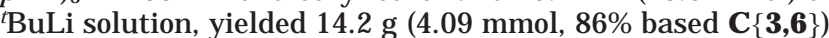
of the title compound. $\mathrm{Mp}$ : $50-55^{\circ} \mathrm{C}$. Anal. Calcd for $\mathrm{C}_{90} \mathrm{H}_{48} \mathrm{~F}_{117}$ $\mathrm{Si}_{3} \mathrm{P}$ : C, 31.2; H, 1.40; F, 64.1; Si, 2.43; P, 0.89. Found: C, 33.9; $\mathrm{H}, 1.68 ; \mathrm{F}, 60.7 ; \mathrm{Si}, 2.66 ; \mathrm{P}, 0.96$. ${ }^{1} \mathrm{H} \mathrm{NMR}\left(\delta ; \mathrm{C}_{6} \mathrm{D}_{6} / \mathrm{C}_{6} \mathrm{~F}_{6}\right.$, $1: 1(\mathrm{v} / \mathrm{v})): 7.35(\mathrm{~m}, 4 \mathrm{H}), 2.05(\mathrm{~m}, 6 \mathrm{H}), 1.08(\mathrm{~m}, 6 \mathrm{H}) .{ }^{31} \mathrm{P}\left\{{ }^{1} \mathrm{H}\right\}$ $\operatorname{NMR}\left(\delta ; \mathrm{C}_{6} \mathrm{D}_{6} / \mathrm{C}_{6} \mathrm{~F}_{6}, 1: 1(\mathrm{v} / \mathrm{v})\right):-4.49 .{ }^{29} \mathrm{Si}\left\{{ }^{1} \mathrm{H}\right\}$ NMR $\left(\delta ; \mathrm{C}_{6} \mathrm{D}_{6} /\right.$ $\left.\mathrm{C}_{6} \mathrm{~F}_{6}, 1: 1(\mathrm{v} / \mathrm{v})\right): 1.25 .{ }^{19} \mathrm{~F}$ NMR $\left(\delta ; \mathrm{C}_{6} \mathrm{D}_{6} / \mathrm{C}_{6} \mathrm{~F}_{6}, 1: 1(\mathrm{v} / \mathrm{v})\right):-81.5$ $(m, 3 F),-115.9(m, 2 F),-121.9(m, 2 F),-122.9(m, 2 F)$, $-123.2(\mathrm{~m}, 2 \mathrm{~F}),-126.3(\mathrm{~m}, 2 \mathrm{~F})$.

Tris[4- $\{$ bis $(3,3,4,4,5,5,6,6,7,7,8,8,9,9,10,10,10-h e p t a-$ decafluorodecyl)methylsilyl $\}$ phenyl]phosphine (D $\{2,8\}$ ). Compound $\mathbf{C}\{\mathbf{2}, \mathbf{8}\}(23.2 \mathrm{~g}, 22.8 \mathrm{mmol})$ in $130 \mathrm{~mL}$ of diethyl ether added to a suspension of $\mathrm{P}\left(\mathrm{C}_{6} \mathrm{H}_{4}-\mathrm{p}-\mathrm{Li}\right)_{3}$, obtained from $3.42 \mathrm{~g}(6.85 \mathrm{mmol})$ of $\mathrm{P}\left(\mathrm{C}_{6} \mathrm{H}_{4}-\mathrm{p}-\mathrm{Br}\right)_{3}$ in $200 \mathrm{~mL}$ of diethyl ether and $27.4 \mathrm{~mL}(41.1 \mathrm{mmol})$ of tBuLi solution, yiel ded $21.0 \mathrm{~g}(6.84$ mmol, $90 \%$ based on $\mathbf{C}\{\mathbf{2 , 8}\}$ ) of the title compound. $\mathrm{Mp:} 72$ ${ }^{\circ} \mathrm{C}$. Anal. Calcd for $\mathrm{C}_{81} \mathrm{H}_{45} \mathrm{~F}_{102} \mathrm{Si}{ }_{3} \mathrm{P}$ : C, 31.65; H, 1.46; F, 63.10; $\mathrm{Si}, 2.73 ; \mathrm{P}, 1.00$. Found: $\mathrm{C}, 31.71 ; \mathrm{H}, 1.41 ; \mathrm{F}, 62.91 ; \mathrm{Si}, 2.72$; $\mathrm{P}, 1.08$. ${ }^{1 \mathrm{H}} \mathrm{NMR}\left(\delta ; \mathrm{C}_{6} \mathrm{D}_{6} / \mathrm{C}_{6} \mathrm{~F}_{6}, 1: 1(\mathrm{v} / \mathrm{v})\right): 7.30(\mathrm{~m}, 4 \mathrm{H}), 2.03$ $(\mathrm{m}, 4 \mathrm{H}), 1.02(\mathrm{~m}, 4 \mathrm{H}), 0.25(\mathrm{~s}, 3 \mathrm{H}) .{ }^{31} \mathrm{P}\left\{{ }^{1} \mathrm{H}\right\} \mathrm{NMR}\left(\delta ; \mathrm{C}_{6} \mathrm{D}_{6} /\right.$ $\left.\mathrm{C}_{6} \mathrm{~F}_{6}, 1: 1(\mathrm{v} / \mathrm{v})\right):-4.70 .{ }^{29} \mathrm{Si}\left\{{ }^{1} \mathrm{H}\right\}$ NMR $\left(\delta ; \mathrm{C}_{6} \mathrm{D}_{6} / \mathrm{C}_{6} \mathrm{~F}_{6}, 1: 1(\mathrm{v} /\right.$ v)): $0.23 .{ }^{13} \mathrm{C}\left\{{ }^{19} \mathrm{~F}\right\}$ NMR $\left(\delta ; \mathrm{C}_{6} \mathrm{D}_{14} / \mathrm{FC}-72,1: 1(\mathrm{v} / \mathrm{v})\right): 140.4(\mathrm{dt}$, 1] $\left.\mathrm{p}, \mathrm{C}=14.0 \mathrm{~Hz},{ }^{2} \mathrm{C}_{\mathrm{C}, \mathrm{H}}=6.7 \mathrm{~Hz}\right), 136.1(\mathrm{~m}), 134.3(\mathrm{dm}), 119.0$ (m), $118.4\left(q,{ }^{1}{ }_{C, F}=262 \mathrm{~Hz}\right), 112.4,112.3,112.0,111.4,109.8$ $\left(\mathrm{qm},{ }^{2} \mathrm{~J} \mathrm{c}, \mathrm{F}=26 \mathrm{~Hz}\right), 26.5\left(\mathrm{tm},{ }^{1} \mathrm{~J} \mathrm{c}, \mathrm{H}=131 \mathrm{~Hz}\right), 3.98\left(\mathrm{t},{ }^{1} \mathrm{~J} \mathrm{c}, \mathrm{H}=\right.$ $123 \mathrm{~Hz}),-6.98\left(\mathrm{q},{ }^{1} \mathrm{~J} \mathrm{c}, \mathrm{H}=120 \mathrm{~Hz}\right) .{ }^{19} \mathrm{~F} \mathrm{NMR}\left(\delta ; \mathrm{C}_{6} \mathrm{D}_{6} / \mathrm{C}_{6} \mathrm{~F}_{6}\right.$ $1: 1(\mathrm{v} / \mathrm{v})):-82.4(\mathrm{~m}, 3 \mathrm{~F}),-117.0(\mathrm{~m}, 2 \mathrm{~F}),-122.8(\mathrm{~m}, 6 \mathrm{~F})$, $-123.7(\mathrm{~m}, 2 \mathrm{~F}),-124.1(\mathrm{~m}, 2 \mathrm{~F}),-127.2(\mathrm{~m}, 2 \mathrm{~F})$.

Tris[4- $\{\operatorname{tris}(3,3,4,4,5,5,6,6,7,7,8,8,9,9,10,10,10-h e p-$ tadecafluorodecyl)silyl $\}$ phenyl]phosphine $(D\{3,8\})$. Compound $\mathbf{C}\{3,8\}(17.2 \mathrm{~g}, 11.9 \mathrm{mmol})$ in $200 \mathrm{~mL}$ of diethyl ether added to a suspension of $\mathrm{P}\left(\mathrm{C}_{6} \mathrm{H}_{4}-\mathrm{p}-\mathrm{Li}\right)_{3}$, obtained from $1.78 \mathrm{~g}$ (3.57 mmol) of $\mathrm{P}\left(\mathrm{C}_{6} \mathrm{H}_{4}-\mathrm{p}-\mathrm{Br}\right)_{3}$ in $200 \mathrm{~mL}$ of diethyl ether and $14.2 \mathrm{~mL}(21.4 \mathrm{mmol})$ of tBuLi solution, yielded $15.3 \mathrm{~g}(3.50$ $\mathrm{mmol}, 88 \%$ based on $\mathbf{C}\{\mathbf{3 , 8}\})$ of the title compound. Mp: 124 ${ }^{\circ} \mathrm{C}$. Anal. Calcd for $\mathrm{C}_{108} \mathrm{H}_{48} \mathrm{~F}_{153} \mathrm{Si}_{3} \mathrm{P}$ : C, 29.67; H, 1.10; F, 66.56; Si, 1.92; P, 0.71. Found: C, 29.66; H, 1.15; F, 66.38; Si, 1.96; $\mathrm{P}, 0.74$. ${ }^{1} \mathrm{H} \operatorname{NMR}\left(\delta ; \mathrm{C}_{6} \mathrm{D}_{6} / \mathrm{C}_{6} \mathrm{~F}_{6}, 1: 1(\mathrm{v} / \mathrm{v})\right): 7.35(\mathrm{~m}, 4 \mathrm{H}), 2.07$ $(\mathrm{m}, 6 \mathrm{H}), 1.09(\mathrm{~m}, 6 \mathrm{H}) .{ }^{31} \mathrm{P}\left\{{ }^{1} \mathrm{H}\right\}$ NMR $\left(\delta ; \mathrm{C}_{6} \mathrm{D}_{6} / \mathrm{C}_{6} \mathrm{~F}_{6}, 1: 1(\mathrm{v} / \mathrm{v})\right)$ : -4.49. ${ }^{29} \mathrm{Si}\left\{{ }^{1} \mathrm{H}\right\}$ NMR $\left(\delta ; \mathrm{C}_{6} \mathrm{D}_{6} / \mathrm{C}_{6} \mathrm{~F}_{6}, 1: 1(\mathrm{v} / \mathrm{v})\right): 1.24 .{ }^{19} \mathrm{~F} N M R$ $\left(\delta ; \mathrm{C}_{6} \mathrm{D}_{6} / \mathrm{C}_{6} \mathrm{~F}_{6}, 1: 1(\mathrm{v} / \mathrm{v})\right):-80.9(\mathrm{~m}, 3 \mathrm{~F}),-115.4(\mathrm{~m}, 2 \mathrm{~F}),-121.4$ $(\mathrm{m}, 6 \mathrm{~F}),-122.3(\mathrm{~m}, 2 \mathrm{~F}),-122.6(\mathrm{~m}, 2 \mathrm{~F}),-125.8(\mathrm{~m}, 2 \mathrm{~F})$.

Solubility Studies. Saturated solutions in the appropriate solvent were prepared by stirring a suspension of the fluorous phosphine for $2 \mathrm{~h}$ at $25^{\circ} \mathrm{C}$. A sample $(3.000 \pm 0.002 \mathrm{~mL})$ was taken after allowing the solution to settle. The total weight of the saturated solution was determined. All solvent was removed in vacuo ( $0.1 \mathrm{mbar}, 15 \mathrm{~h}$ ), after which the weight was constant within $\pm 0.001 \mathrm{~g}$, and the weight of the residue was determined.

Determination of Partition Coefficients. The partition coefficients were determinded by dissolving a known amount of phosphine (typically between 11 and $60 \mu \mathrm{mol}$ ) in a fluorous biphasic system consisting of $\mathrm{c}^{-} \mathrm{C}_{6} \mathrm{~F}_{11} \mathrm{CF}_{3}(2.000 \pm 0.002 \mathrm{~mL})$ and either $\mathrm{n}$-pentane, $\mathrm{n}$-octane, or toluene $(2.000 \pm 0.002 \mathrm{~mL})$. The resulting mixture was stirred at $25{ }^{\circ} \mathrm{C}$ until all of the solid had dissolved, and the mixture had equilibrated in a water/ ice bath $(1 \mathrm{~h})$. An aliquot $(0.500 \pm 0.002 \mathrm{~mL})$ was removed from each layer by syringe. Analysis by ICP-AAS on phosphorus gave the amount of phosphine present, with an accuracy of $\pm 0.3 \mathrm{ppm}$. A conservative estimate of the experimental error in the partition coefficient is \pm 1 in the last digit.

Acknowledgment. We thank $\mathrm{H}$. Kleijn and Dr. J. T. B. H. J astrzebski (Utrecht University) for valuable advise and Elf Atochem and U-Cat (Utrecht) for financial support.

Supporting Information Available: I mproved synthetic procedures for known compounds $\mathbf{C}\{\mathbf{1}, \mathbf{6}\}, \mathbf{C}\{\mathbf{1}, \mathbf{8}\}$, Grignards $\mathbf{A}\{\mathbf{x}\}(\mathbf{x}=6,8), \mathbf{C}\{\mathbf{3}, \mathbf{6}\}$, and tris(p-bromophenyl)phosphine; ${ }^{1} \mathrm{H}$ NMR spectra of compounds $\mathbf{B}\{\mathbf{2}, \mathbf{6}\}, \mathbf{C}\{\mathbf{2}, \mathbf{6}\}, \mathbf{C}\{\mathbf{3}, \mathbf{8}\}, \mathbf{E}\{\mathbf{1}, \mathbf{6}\}$, 1,4- $\left[\mathrm{C}_{6} \mathrm{~F}_{13}\left(\mathrm{CH}_{2}\right)_{2} \mathrm{SiMe}_{2}\right]_{2} \mathrm{C}_{6} \mathrm{H}_{4}, \mathbf{E}\{\mathbf{1}, \mathbf{8}\}$, and 1,4- $\left[\mathrm{C}_{8} \mathrm{~F}_{17}\left(\mathrm{CH}_{2}\right)_{2-}\right.$ $\left.\mathrm{SiMe}_{2}\right]_{2} \mathrm{C}_{6} \mathrm{H}_{4} ;{ }^{13} \mathrm{C}$ NMR spectra of compounds $\mathbf{B}\{\mathbf{2}, \mathbf{6}\}, \mathbf{C}\{\mathbf{2}, \mathbf{6}\}$, $\mathbf{E}\{\mathbf{1 , 6}\}, 1,4-\left[\mathrm{C}_{6} \mathrm{~F}_{13}\left(\mathrm{CH}_{2}\right)_{2} \mathrm{SiMe}_{2}\right]_{2} \mathrm{C}_{6} \mathrm{H}_{4}, \mathbf{E}\{\mathbf{1}, \mathbf{8}\}$, and 1,4-[ $\mathrm{C}_{8} \mathrm{~F}_{17}\left(\mathrm{CH}_{2}\right)_{2-}$ $\left.\mathrm{SiMe}_{2}\right]_{2} \mathrm{C}_{6} \mathrm{H}_{4}$; and ${ }^{19} \mathrm{~F}$ and ${ }^{29} \mathrm{Si}$ NMR spectra of compounds $\mathbf{B}$ $\{\mathbf{2}, \mathbf{6}\}, \mathbf{C}\{\mathbf{2}, \mathbf{6}\}, \mathbf{C}\{\mathbf{3}, \mathbf{8}\}$, and $\mathbf{E}\{\mathbf{1}, \mathbf{6}\}$. This material is available free of charge via the Internet at http://pubs.acs.org.

J O991548V 